\title{
ORIGINALIDAD Y ESTÍMULOS MEDITERRÁNEOS EN LA CERÁMICA IBÉRICA: EL EJEMPLO DE ELCHE
}

\author{
RICARDO OLMOS \\ C.S.I.C. Madrid \\ Arturo D. Trendall, \\ Octogenario, \\ Optumo antecessori, \\ Scriptori prolifico, \\ Pectore ab imo.
}

\begin{abstract}
Dans ce travail, nous analysons l'iconographie de la céramique ibérique du Sud-Est espagnol, nous centrant sur l'exemple d'Elche (dpt. Alicante), dont le floruit se situe à l'époque hellénistique (IIIe à ler s. a.C.). Face aux interprétations comparatistes antérieures, qui essayaient de voir la représentation locale comme un simple reflet d'autres cultures méditerranéennes, à travers fondamentalement les mondes figuratifs grecs et puniques, nous proposons ici un modèle qui explique internement ces images, sans pour autant renoncer, dans des cas concrets, à y reconnaître une influence formelle -et religieuse - hellénisante ou punique. Les représentations végétale, animale et humaine constituent une structure organique dans laquelle les éléments se remplacent alternativement ou se codéfinissent les uns les autres, et dans laquelle les exceptions apparentes peuvent trouver une justification interne dans l'univers figuratif ibérique lui-même.
\end{abstract}

En este trabajo analizamos la iconografía de la cerámica ibérica del Sudeste español centrándonos en el ejemplo de Elche (Alicante), cuyo floruit productivo se sitúa en época helenística (III-I a.C.). Frente a las interpretaciones comparatistas anteriores, que buscaban en la representación local un simple reflejo de otras culturas mediterráneas, a través fundamentalmente de los modelos figurativos griegos y púnicos, proponemos aquí un modelo que explique internamente estas imágenes, sin renunciar, por otra parte, en casos concretos a reconocer en ellas una determinada influencia formal - y hasta religiosa - helenizante o púnica. Las representaciones vegetal, animal y humana constituyen una estructura orgánica en la cual los elementos se sustituyen alternativamente codefiniéndose unos a otros. Las excepciones aparentes pueden hallar una justificación interna dentro del propio universo figurativo ibérico.

\section{UN APUNTE HISTORIOGRÁFICO}

Desde sus inicios los estudios de cerámica ibérica han estado marcados por la búsqueda de unos modelos mediterráneos generalmente helenizantes bajo cuyos influjos se ha querido situar el origen y desarrollo de sus motivos figurativos y formales. Una y otra vez los estudiosos han intentado buscar un centro colonial a estos estímulos que han actuado sobre una cultura como la ibérica, considerada 
periférica o provincial. En no pocas ocasiones se ha enfocado el tema bajo unas categorías marcadamente comparatistas y, en consecuencia, reduccionistas: se explicaba prioritariamente el fenómeno ibérico por sus modelos; quedaba practicamente aquél reducido a éstos, pues interesaban más las similitudes que las diferencias.

A finales del siglo XIX y bajo el influjo de los espectaculares descubrimientos del Mediterráneo oriental se buscaron en las cerámicas micénica y chipriota del Bronce Final las primeras analogías para la cerámica ibérica. Este mundo recién descubierto, fue valorado sobre todo en la obra del investigador francés Pierre Paris (Paris, 1905; 1904, 134: Elche). Cuando en un segundo momento, ya entrado el siglo $\mathrm{XX}$, se empezaron a conocer las primeras representaciones figuradas ibéricas - por ejemplo, con el llamado vaso de los Guerreros de Archena, publicado por primera vez en 1912 (J.P.S., 1911-12, 685; SANDARS, 1913, pls. 7-8; OLMOS, 1987) - se acudió a la comparación de estos productos con la cerámica griega de Figuras Negras y Figuras Rojas, así como con la anterior orientalizante (BOSCH GIMPERA, 1915; IDEM, 1958; CARPENTER, 1925, 82 ss; OLMOS, en prensa). $\mathrm{El}$ principal representante de esta tendencia fue $\mathbf{P}$. Bosch Gimpera: sustentaba esta postura en la creciente presencia de importaciones áticas, especialmente durante los siglos V y IV a. c., en la mayoría de los yacimientos costeros ibéricos (BOSCH GIMPERA, 1928, 163-178; BALLESTER, 1943, 64-67). También influyó en esta apreciación la sobrevaloración que la historiografía de entonces dedicó al fenómeno colonial, bien documentado por la realidad de la focea Ampurias -en el Nordeste de la Península Ibérica - mal conocido en cambio para los otros asentamientos griegos - como los debatidos casos de Hemeroscopeion, Alonis o Mainake-que escueta y confusamente nos transmiten las fuentes (GARCIA Y BELLIDO, I, 1948, 130; II, 3 ss., 5158). Su existencia no se ponía entonces en duda: era preciso dotar de funciones helenizadoras a estos asentamientos (CARPENTER, 1925, 48-49, 54, 93).

Se intentó incluso $-\mathrm{y}$ con resultados que dieron su fruto- encuadrar el estudio de la cerámica ibérica en el de la cerámica griega y suritálica y se publicaron de este modo dos Corpora Vasorum Hispanorum, siguiendo las directrices y el formato del $C V A$, en una clara dialéctica nacionalista pero con enfoques más renovadores y arqueológicos que los de su modelo anticuarista (CABRE, 1945; BALLESTER TORMO ET ALII, 1954; OLMOS, 1989). En esos años se inicia paralelamente el enfoque positivista; uno de los objetivos prioritarios es la datación de la cerámica ibérica fundamentándola en la estratigrafía, en su situación contextual en los yacimientos. García y Bellido formula con claridad el problema en 1943: el objetivo fundamental de la investigación «es hallar una sistematización cronológica no ya a la cerámica, sino a todo el arte español antiguo, no romano" (GARCIA Y BELLIDO, $1943,89)$. Sigue a éste otro enfoque, el clasificatorio, basado en la taxonomía tipológica, esto es, en la fijación de tipos, formas, motivos, temas, etc., de la cerámica. Tal es en lo fundamental el enfoque de los trabajos de la investigadora sueca S. Nordström: aplica un razonamiento analítico - abstrae, descompone el vaso y la imagen en sus múltiples elementos constitutivos- y simultaneamente le guía un afán comparativo característico de los tipologistas: acumula paralelos pero no llega a crear la estructura o modelo integrador que explique el conjunto (NORDSTRÖM, 1969, 1973, 97-120).

Volvamos al problema de la cronología. El estudio de los yacimientos del Levante y Sureste español en estos últimos decenios ha venido confirmando una fecha generalmente tardía para la cerámica pintada ibérica que alcanza su floruit precisamente en los años en que las importaciones áticas ya no se importan en la Península, es decir a partir de los decenios finales del siglo IV a. de C. (FLETCHER, 1943, 109-115). Nos hallamos pues con una expansión de la cerámica ibérica decorada en plena época helenística: segunda mitad del siglo IV y, sobre todo, siglos III al I a. de C. Ello responde, paradógicamente, a un momento en el que la cerámica pintada en Grecia y en el Sur de Italia ha entrado en clara decadencia para sustituirse, bien por una cerámica decorativa y ornamental como son los estilos de Gnatia - frente a la anterior cerámica figurativa - bien por el predominio de nuevas técnicas artesanales y productivas como es el creciente uso del molde y de las estampillas con su multiplicación mecánica de los esquemas ornamentales o, sobre todo, la producción masiva de las diversas cerámicas campanienses de barniz negro, como vajilla de mesa (MOREL, 1961). Es esta última la cerámica funcional que coexistirá simultaneamente en los yacimientos ibéricos con la exuberante cerámica decorada ibérica. Se da un claro contraste entre la monótona cerámica lisa o estampillada importa- 
da y la enorme riqueza formal e iconográfica de algunas producciones locales.

Este desfase cronológico entre las cerámicas pintadas áticas y la figurada ibérica -ésta surge cuando aquélla cesa - llevó lógicamente a otros autores a Ia búsqueda de modelos diferentes, más acordes con la situación histórica de la época en que esta última se produce. Se proponen ahora influjos muy directos del mundo púnico, que llegarían a través especialmente de la antigua colonia cartaginesa en la isla de Ibiza y por la presencia de los Bárcidas en el Levante español durante el siglo III a. C., en la segunda guerra púnica (FIGUERAS, 1956; LAFUENTE VIDAL, 1952, 160-177). A la fundación, si bien efímera, de Carthago Nova se atribuirá ahora un papel artesanal y difusor de las ideas y motivos del Mediterráneo (RAMOS FOLQUES, 1973, 363383; IDEM, 1955). Responde esta postura al afán por vincular el dato histórico con el arqueológico lo que llevó a algunas interpretaciones a veces poco fundadas, otras demasiado rígidas. Sobre todo se intentó reconocer estos influjos históricos a través de la iconografía, un campo ambiguo y subjetivo $\mathrm{y}$, por lo tanto, el más adecuado para acomodar hipótesis y datos al pensamiento propio. Se propuso, por ejemplo, para determinadas representaciones femeninas ibéricas su pertenencia a las esferas religiosas de la diosa púnica Tanit -o, incluso, en un claro desfase cronológico e histórico a la Astarté fenicia - o de la diosa grecooriental Artemis efesia (RAMOS FOLQUES, 1953, 330; BLAZQUEZ, 1975, 30-38, s.v. Astarté). Nos referiremos a algunos casos concretos más adelante, cuando analicemos los ejemplos de Elche (finalmente, MARIN CEBALLOS, 1987). Surgen pues, aquí y allá, con justificación o no, tendencias que buscan paradigmas y apoyos externos al propio mundo ibérico. Ello también se explica por la necesidad de encontrar en toda ciencia tanto un campo de contrastación de la realidad como un sistema en el que integrar los datos dispersos y el conocimiento puntual. Apenas ha existido, es cierto, la posibilidad de efectuar este contraste en el mundo ibérico: pues, al contrario de lo que ocurre con las investigaciones tradicionales en arqueología clásica, ha faltado aquí el apoyo y el contraste de las fuentes escritas antiguas. No ha podido desarrollarse una «Arqueología filológica» como en el mundo clásico, con sus limitaciones metodológicas, es cierto, pero también con sus inmensas aportaciones en el campo de la religión o de los realia. Pero aquí las referencias de los autores gre- corromanos sobre la Península son, por lo general, escasas. Y consideraron siempre el mundo indígena desde un ángulo de observación externo y condicionado, en ocasiones, al programa imperial romano, como es el caso del Libro III de Estrabón, una de las principales fuentes que poseemos para la España antigua (ARCE, 1990).

\section{EL PROBLEMA DE LAS IMITACIONES}

En estos últimos años la visión del mundo ibérico se ha ampliado enormemente. Se han revisado muchos de los postulados anteriores bajo una luz más crítica. También en el estudio de la cerámica se ha empezado a analizar la compleja amalgama de los influjos griegos, especialmente en lo que a la adaptación formal se refiere. Se constata la imitación de numerosas formas ya en los mismos siglos V y IV a.C., sobre todo en aquellas áreas en que la presencia de material griego - principalmente cerámica ática- está presente (PAGE, 1984; BONET y MATA, 1988, 5-38). Se ha comprobado además el frecuente desfase cronológico entre las imitaciones y las fechas que habitualmente se atribuyen a la cerámica ática, como es el caso de la cratera de columnas. Se imitó especialmente este vaso arquitectural en el mundo ibérico de Andalucía Oriental y del Sureste español (PAGE, 1984, 66-69; PEREIRA, 1979, 289-348). Como en el Sur de Italia, se populariza también aquí la cratera de columnas en el siglo IV, seguramente como vaso de prestigio y, en ocasiones, como vaso funerario (OLMOS, 1981, 259-268). La forma pervive durante decenios cuando el modelo ático ya ha desaparecido. Junto con las cuestiones cronológicas que las imitaciones suscitan, este aspecto de las influencias mediterráneas en las creaciones locales se ha empezado a comprender como un proceso dialéctico e integrador dotado de una dinámica propia, y no ya sólo como una mera aceptación pasiva por la sociedad ibérica de los estímulos formales helenizantes. Las imitaciones se incorporan a una estructura o sistema previo, modificándolo. De ahí, que en el resultado de la mayoría de las imitaciones, tengamos verdaderos productos ibéricos, no simples copias de formas griegas. No sirve, veremos, en la mayoría de los casos, la nomenclatura actual - y convencional- de los vasos griegos para describir el universo formal tan específico de la cerámica ibérica. 
Este proceso de las imitaciones no es unívoco es decir, no implica una relación sencilla e inmediata entre el modelo griego y la copia indígena- sino que se manifiesta con frecuencia como un entramado muy complejo y multidireccional (OLMOS en PAGE, 1984, 268-277). Por lo general, no se copia el modelo directamente -en el mundo productivo antiguo no existió como tal este concepto de copia, que es moderno- sino la idea, el aire de ese modelo o elementos concretos y particulares de un vaso - las asas, el pie, etc.-. Se sigue un proceso fundamentalmente analítico - que es como lo ve el ibero-y no intuitivo y global del objeto - que es como lo suele ver el griego clásico-. No pocas veces son las mismas imitaciones locales las que generan a su vez imitaciones: surgen así lo que llamaríamos imitaciones de segundo o tercer grado. Y, lo que es aún más significativo, en algún caso aislado las imitaciones llegan incluso a producirse en un sentido inverso al habitual. Es cierto que, generalmente, las imitaciones se producen de modelos en material valioso - por ejemplo, en metal, mármol o alabastro- para vertirse en arcilla. Sin embargo, en la vajilla de Abengibre (en Albacete) se reproducen en plata precisamente algunos modelos cerámicos de Barniz Negro áticos del siglo IV, como los cuencos de reborde entrante: es en la plata donde mejor puede el ibero reproducir la calidad del barniz negro ático y, sobre todo, su decoración: las palmetas, impresas en el modelo, serán aquí incisas. En una sociedad que basa su poder comercial en las transacciones argentíferas, la plata además, como expresión de valor, manifiesta el status económico y de prestigio de quien adopta la moda helenizante. Al imitarse en plata una vajilla de cerámica vemos reforzada por parte del ibero la valoración de estas importaciones áticas.

Resulta sintomático que las investigaciones de estos últimos años se hayan centrado principalmente en el ámbito de las imitaciones formales y sólo en menor medida en el de las figurativas lo cual, dijimos, había sido objeto sobre todo de las lucubraciones de nuestros predecesores (OLMOS, en prensa). Se debe esto no sólo al escepticismo ante algunos resultados excesivamente genéricos $\mathrm{y}$, por tanto, estériles, de los pasados decenios, sino también al hecho de que la imitación de motivos figurados apenas encuentra una correspondencia sistemática con la imitación formal del soporte. No son procesos simultáneos, lo que refuerza nuestra impresión de que en el gesto de la imitación cerámica el ibero proce- de, como decíamos, de un modo analítico más que sintético: desdobla los elementos a imitar, no concibe el vaso - forma y decoración- como un conjunto, como una unidad, al modo griego. Posiblemente influye además en esta renuncia a imitar la imagen, el peso de la gran tradición anicónica de la cerámica ibérica en los primeros siglos (V y IV a. de C.) en que, en cambio, surge el principal movimiento mimético de las formas (excepciones en RAMOS FOLQUÉS y RAMOS FERNANDEZ, 1976, 45, lám. XCVIII y figs. 63-4). Ello tiene, además, una justificación social, no meramente psicológica o estética. El contexto de la imagen para el ibero se mueve dentro de unos parámetros diferentes de, por ejemplo, los del girego, bien sea éste de la Grecia misma o del Sur de Italia. Para el griego del clasicismo la imagen surge y se justifica plenamente dentro del desarrollo mismo de la pólis (VERNANT et alii, 1984). La iconografía forma parte integrante de la vida de la ciudad como expresión de su evolución política: cuando, a mediados del siglo IV, la pólis clásica se desintegra con el surgimiento del temprano helenismo, la cerámica figurativa griega se encerrará cada vez más en un mundo simbólico y decorativo - cerámica del Sur de Italia, cerámica mediterránea de la época helenística-, muy alejada ya del sentimiento colectivo de la vida ciudadana de la que aquélla fue expresión.

En este sentido podemos afirmar que el artesano ibérico es aquí más libre que, por ejemplo, el etrusco, quien introdujo de una manera muy directa técnicas de la cerámica ática como la de Figuras Negras o las Figuras Rojas, en una dinámica imitativa muy compleja y rica (BEAZLEY, 1947, reimp. 1976). La relación del etrusco con el mundo griego es en este sentido mucho más matizada e intensa. Recordemos, para las Figuras Rojas, el afán mimético de algunos talleres indígenas etruscos y suritálicos donde se simula más o menos servilmente la apariencia de los modelos áticos con las Pseudofiguras Rojas, en los vasos llamados del Rojo Superpuesto bien estudiados por J. Gy. Szilágyi (BEAZLEY, 1947, 195; SZILAGYI, 1975, 13-28). La técnica se adopta porque es necesaria para reinterpretar, de modo original, la mitología e iconografía griegas bajo la dinámica ideológica propia del etrusco. El pintor ibérico no conocerá un proceso similar que reproduzca las técnicas pictóricas griegas. No necesitará éstas.

Sólo cuando en los albores del siglo IV y durante el helenismo la cerámica se industrializa en el ám- 
bito mediterráneo con las poroducciones masivas de barniz negro - lisas o estampilladas - se intentará esporádicamente reproducir este mismo proceso artesanal en el mundo ibérico (BONET-MATA, 1988, 28). Cuando algunos talleres del Sureste que imitan las producciones helenísticas de Italia y de Rosas (Gerona) tratan de reproducir dicho proceso en la cerámica local, vemos incluso cómo la decoración con estampillas desborda en aparente desorden los platos y copas en que se aplican (fig. ), extendiéndose incluso a zonas del vaso que en principio habrían de ser funcionales y no receptoras de decoración como las mismas asas en una copa de Jumilla, en Murcia (PAGE, 1984, fig. 26,2,7). Nos hallamos ante una espontánea reacción psicológica del ceramista ibérico que no da crédito a sus ojos ante las posibilidades de multiplicar indefinidamente con un mismo sello los motivos decorativos, en lugar de la utilización del pincel. Fascina aquí al artesano local, sobre todo, el repentino descubrimiento de la novedad técnica. Pero la cerámica ibérica sigue anclada en el proceso productivo antiguo - el de la decoración pintada, que comporta una consideración individual de cada vaso, no la perspectiva de la producción global-y no crea las bases revolucionarias de la nueva técnica, extendida sobre todo en el mundo itálico del helenismo y en el asentamiento griego de Rosas, en Gerona, en el Nordeste de la Península Ibérica (SANMARTI, 1978). Rosas alcanzará una situación pujante desde el siglo IV por esta industria. Las producciones cartaginesas y de Ibiza representan el otro polo de la competencia de importaciones en el mercado peninsular (PAGE, 1984, 164 ss; BONET y MATA, 1988, 16-21). La producción en serie requiere, además, unos medios adecuados para una distribución competitiva de los productos y la expansión del mercado en gran escala: una infraestructura de la que careció el mundo ibérico. Creo que en esta línea habría que buscar, en parte, las causas que justificaran la enorme retardación de la cerámica ibérica tanto en las formas como en la iconografía: mantienen durante siglos los mismos motivos iconográficos y hasta las mismas formas, pues ni la técnica ni el sistema productivo - ni la misma sociedad que las demanda - varían en profundidad. Se mantiene una estructura social e ideológica retardataria. Muchos de los temas, veremos, responden a un tipo de sociedad heroico $\mathrm{y}$, en algunos aspectos, marcadamente arcaizante. Recuerdan muy de cerca esquemas itálicos, de tradición indígena, como los de la cerámica polícro-
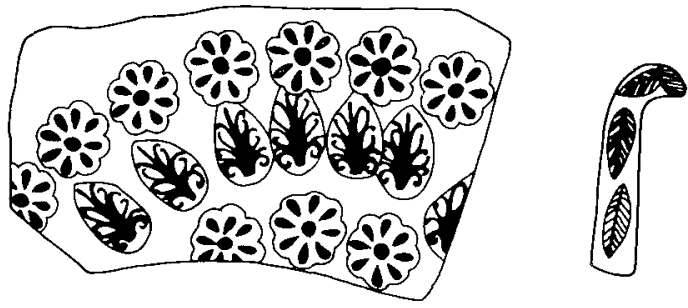

Fig. 1.

ma de Arpi, recientemente estudiados por Marina Mazzei (MAZZEI, 1987, 167-188). Baste comparar, en estructura formal y en lenguaje compositivo, los combates singulares a caballo de los vasos de Arpi con el llamado cálato de los guerreros de Archena (OLMOS, 1987). Se responde en ambos casos a la demanda de una ideología aristocrática local. La cerámica ibérica pintada mantendrá incluso este sistema tan tradicional hasta bien entrada la época imperial romana y coexistirá durante largo tiempo con la masiva comercialización de la cerámica sigillata. Sólo la paulatina afirmación de los usos productivos romanos cambiará este estado de cosas.

Otra variable, la funcional, representa un segundo aspecto de las imitaciones en el que apenas se ha indagado. Hemos visto en otro lugar cómo la imitación de las crateras - de campana o de columnas - parece en parte adaptarse en el mundo ibérico andaluz al uso local del vaso concebido metafóricamente como casa, como estructura arquitectónica (OLMOS, 1981). No podemos hoy pues probar que la importación de una cratera de campana o de columnas griega implique necesariamente la introducción del rito griego del simposio, aún cuando se acompañe de kylikes, como conjunto, lo que es frecuente en las Necrópolis de Andalucía Oriental, como Baza o Galera en Granada, donde tendríamos el contraste entre el vaso comunitario, la gran cratera, y la copa de posesión individualizada (Baza: PRESEDO, 1982, lams. 17-20; pls. 29-34; Andalucía: TRIAS, 1967, II, láms. 203215). Tampoco la imitación implica, sin más, la aceptación del uso griego. En todo caso la imitación de la cratera o de las copas puede responder aquí a una muestra de prestigio: la cratera pasaría a convertirse, en un determinado momento, en un símbolo de clase, de preeminencia social, por ejemplo de aquéllos que a través de las rutas comerciales se hallan en contacto con los comerciantes mediteráneos y con los productos y la moda de Grecia, como en el enterramiento de l'Orleyl, en Castellón 
(OLMOS y DE GRIÑO, 1985, 24-26; OLMOS, 1984, 221, fig. 3). En algún contexto el vaso de beber aislado - la copa, el cántaros, el escifo- puede transformarse semánticamente en un signo de afirmación de la individualidad: lo constatamos, por ejemplo, en el gesto funerario de inutilizar cuidadosamente el vaso de beber que ha de acompañar a su poseedor en la tumba, como vemos en algún ejemplo de la Necrópolis de Pozo Moro, en Albacete (OLMOS, 1984, 220). Pero si en el contexto originario ático los vasos se integran en ajuares, en estructuras que mutuamente se explican y justifican formal y funcionalmente como un todo - las crateras en las que se mezcla el vino colectivo no son concebidas sin la presencia del diverso juego de copas individuales que se intercambian en el banquete- en el mundo ibérico no es frecuente encontrar la imitación de ajuares con esta misma estructura sino más bien de elementos sueltos. Lo mismo podríamos indicar en relación con la iconografía importada: la actitud del ibero ante las imágenes de los vasos debe analizarse de un modo dialéctico. Proyecta aquéllas a su propio universo económicosocial, cultural y religioso. No podemos comprenderla sólo desde el lenguaje griego.

Es clara, en el ámbito del Sureste ibérico que preferentemente nos ocupa, la imitación formal, decorativa y funcional, de la fíala o patera mesómphalos o del plato de pescado (PAGE, 1984, 156-158 (fíala); 111-117 (platos de pescados). En el primer caso, conocemos modelos e imitaciones que coexisten en un mismo yacimiento, como la Serreta de Alcoy, en Alicante: junto a una patera calena de barniz negro en relieve, con Erotes entre aves y flores -una estilización del tema clásico de Eros, en el Jardín de Afrodita - (ABAD CASAL, 1983, 173-197), tenemos un ejemplar local en decoración pintada con el mero juego ornamental de las ramas (PAGE, 1984, fíg. 25,5; lám. 2, p. 157). Los gallones del modelo, realizados a molde, se pintan en la imitación. Una imitación, ya en grado secundario, la tendríamos en una fíala de Elche con aves en fila, alternando con rosetas (PERICOT, 1979, 107). En el sencillo friso unidireccional de este vaso, el ibero ha ornamentalizado y simplificado los elementos iconográficos fundamentales de las pateras helenísticas: mantiene los símbolos de la naturaleza vegetal - rosetas - y animal -aves - en torno a un ómphalos cuya estructura geométrica y semiesférica se acentúa y refuerza espacialmente mediante círculos y metopas. La sintaxis, que en los originales itálicos aglutinaba a los diferentes elementos icónicos, se ha disuelto aquí en un lenguaje paratáctico, analítico. Hay, en éste y en la mayoría de los casos ibéricos, una búsqueda de la claridad que evita la acumulación simultánea de dos figuras o dos elementos en un plano único: el ceramista entiende que las figuras se desarrollan siempre sobre un pıano y la imagen debe someterse a esta norma. Al contrario de los pintores áticos y suritálicos, el ibero raramente introduce el ilusionismo y la tercera dimensión en la superficie de un vaso de cerámica.

También son claras las imitaciones en los platos de pescado. Hay algunos ejemplares muy significativos en el poblado ibérico de Liria, en la provincia de Valencia (PAGE, 1984, 11-114, figs. 16-17; BONET y MATA, 1988, f. 2). En un plato de Benidorm (Alicante) los pescados — probablemente atunes - se ordenan y encauzan en las bandas pintadas como en su emigración en torno a la línea de la costa (PAGE, 1984, n. 105, f. 16). Así lo concibe el ibero, en su ordenación geométrica del vaso y, metafóricamente, del cosmos. Tal vez se refleja, estilizadamente, la actividad económica de las almadrabas mediterráneas. El contraste de estos ejemplos con la ordenación libre y la variación de la fauna marina que hallamos en los platos de pescado suritálicos es significativa en cuanto refleja con claridad una visión de la naturaleza diferente (TRENDALL y MAC PHEE, 1987).

Con todo la interpretación funcional de una forma imitada no resulta siempre tan inmediata como en estos casos de la fíala - su uso ritual en las libaciones es evidente- o del plato de pescado. Así ocurre con una pequeña serie de cajitas que llamaríamos píxidas, según la nomenclatura de lo que suponemos, de una manera secundaria y no inmediata, el modelo griego (BLANCO, 1963, 91). En las píxidas ibéricas , como en los ejemplares de Toya (Jaén) (GARCIA Y BELLIDO, 1976, p.602, f. 535; 1947, 264, f. 305; ARRIBAS, 1965, lám. 16) o de Alcoy (Alicante) (PAGE, 1984, 102-103, lám. 3; PERICOT, 1979, 136, f. 184) encontramos la interpretación local de un viejo modelo mediterráneo que hallamos tanto en la cerámica arcaica de Grecia Oriental como en el mundo etrusco: tienen en común estas cajitas el remate de la tapadera, en forma de paloma (LAMB, 1932, 12, lám. 1,4: bucchero eolio; LEVI, 1935, 111: bucchero etrusco). En las cajitas de Toya la asociación de la paloma con los círculos podría ser, iconográficamente, significativa. Pensamos de inmediato en vasos seguramente del ámbito fe- 
menino. Estructuralmante recuerda las lebetas nupciales adornadas con aves y palmetas pintadas de la cerámica beocia del clasicismo (JOHNSON, 1949, 244-5, láms. 34-35). No podemos saber si también en estos vasos se relacionarían con el culto a alguna divinidad de la fecundidad, como la griega Afrodita, vinculada a la paloma y a los perfumes. Ello justificaría la imitación puntual de un modelo precisamente en un contexto social, como el ibérico andaluz o levantino, en el que las imitaciones de las formas responden generalmente al ámbito del varón, no al ámbito de la mujer. Es decir, tal vez se imita e introduce puntualmente una forma del mundus muliebris por su asociación o pertenencia al culto. Pero estamos presuponiendo aquí, ya en el ámbito del contenido, más allá de la forma, la pertenencia de estos casos del mundo ibérico andaluz y levantino, a una aparente koiné religiosa - $\mathrm{o}$ 'cosmopolitismo', si se prefiere este término, a través de la expresión sagrada - en el supuesto ámbito de la mujer: ¿es lícito proponer este indicio sobre el mero análisis tipológico e iconográfico de una forma? La asociación estructural e iconográfica —caja, paloma sobre la tapadera y círculos además en los casos de Toya - serían hoy por hoy el único apoyo que poseemos para esta propuesta. Una ampliación de estas secuencias formales - hoy inexistente- permitirán transformar la simple conjetura en un dato contrastado y positivo.

\section{El ejemplo de Elche: el horizonte las importaciones griegas}

Una consideración de la cerámica ibérica pintada en el yacimiento de Elche, en Alicante, va a centrar la segunda parte de nuestro trabajo, concretando aquí las consideraciones, de índole más teórica, anteriores.

El área de Elche fue durante la época prerromana una de las zonas de la Iberia más intensamente abiertas al influjo de la moda helenizante (LLOBREGAT, 1972, 78-86). Pero simultaneamente Elche estuvo abierta al comercio y a los elementos culturales púnicos que, en determinados momentos - como, por ejemplo, en el temprano helenismoparecen incluso más intensos que los propiamente griegos (RAMOS FOLQUES, 1943, 330).

Los hallazgos de cerámica griega son frecuentes tanto en la misma Elche -por ejemplo, en el llamado yacimiento de la Alcudia - como en su en- torno. Uno de los documentos griegos más antiguos y significativos que conozco - junto con otras importaciones grecoorientales de esta época en la zona- lo tenemos en una pequeña copa ática de mediados del siglo VI a. de C. con el interior decorado, como en las coetáneas copas samias, con bandas y líneas que aquí son de barniz diluido (RAMOS FERNANDEZ, 1987, 57). Una dedicación genérica pintada adorna los dos lados exteriores de esta kylix, en la zona de las asas: HO ПAI $\Sigma$ KA $\Lambda O \Sigma$, 'el muchacho (es) bello', una dedicatoria bien adecuada al uso individualizado, personal, de la copa, fórmula que se ha relacionado ultimamente con el comercio de lujo (ROSS HOLLOWAY, 1987, 9-12). Situamos la copa en el momento final de la expansión comercial focea con Iberia y Tartessos, correspondiendo pues con la presencia griega que se documenta con especial abundancia e intensidad en el Sur Peninsular, en Huelva (OLMOS, 1982, 396-406; CABRERA-OLMOS, 1985, 61-74). Pero también puede corresponder ya al inicio del secundario y posterior comercio del emporio ampuritano, como foceos de Occidente que toman el relevo en las transacciones de la metrópolis. Por las características de la copa es más probable lo primero. Cobraría así pleno sentido el pasaje herodoteo $(I, 163)$ : 'fueron los habitantes de Focea los primeros que realizaron largos viajes por mar y quienes descubrieron el Adriático, Tirrenia, Iberia y Tartessos'. Dentro de la generalización geográfica con que el autor griego emplea el término Iberia, ¿no correspondería efectivamente uno de los puntos de esta Iberia herodotea con el área del Sureste español que nos ocupa, teniento en cuenta que ésta es una de las zonas peninsulares más fuertemente helenizadas desde el mismo siglo VI a. de C., cuando los foceos recorren con sus veloces penteconteras las costas de España? Nuestra copa, asi adornada, podría ser un regalo individual: el objeto que el comerciante ofrece como presente para introducirse en un nuevo mercado.

Son relativamente frecuentes las importaciones de cerámica ática de Figuras Rojas en la zona - Portus Illicitanus, el Molar, Cabezo Lucero, Elche, etc. - , de la segunda mitad del siglo $V$ y sobre todo del IV a.C., que denotan ya seguramente la competencia del comercio ampuritano frente al púnico con base en Ibiza (SANCHEZ, BLASCO y GUARDIOLA, 1986, 50-53; TRIAS, 1967, lám. 175, 4-8 (Elche); lám. 176 (El Molar); lám. 175, 9-13 (Cabezo Lucero); BLANCO, 1960, lám. 33 a). Los vasos del 
siglo $\mathrm{V}$ poseen una cierta calidad, se documentan formas no demasiado comunes en otros yacimientos de la península, como el ánfora de asas trenzadas y las crateras de columnas (SANCHEZ, BLASCO y GUARDIOLA, 1986, 50-53) junto con las mucho más frecuentes crateras de campana (TRIAS, 1967). Este horizonte más selecto del siglo V apunta, por sus pintores y formas, al comercio ampuritano. Pero sobre todo en el siglo IV resulta difícil atribuir quiénes - griegos o púnicos- son los intermediarios de estos productos hasta el área de Elche.

Un medallón recortado de un fragmento de copa ática de Figuras Rojas de Elche, en el Museo Arqueológico de Madrid, con la imagen de un pato, nos abre a un fenómeno más amplio del mundo ibérico: la reutilización secundaria por el indígena delfragmento, que corta cuidadosamente, con un sentido de uso diferente del vaso completo ordinario (1). La figura del pato apunta a una posible reinterpretación o mitologización del indígena del motivo banal ático: nos anticipa la representación mítica del ave, muy popular en la cerámica ibérica.

También del área de Elche, si bien algunos kilómetros al interior, procede una imitación de cerámica ática, concretamente una cratera de columnas, del recinto fortificado ibérico de la Peña Negra (GONZALEZ PRAT, 1986, 254, f. 70). Conozco al menos dos fragmentos de crateras de columnas áticas en Elche. Esta imitación nos relaciona la forma importada con su adopción indígena, dentro de una misma zona. Todo ello - original y copia- nos sitúa en el horizonte de un sector de la población indígena que se muestra permeable al comercio y a la moda griega.

\section{LA GRAN ESCULTURA DE ELCHE}

La introducción de la moda helenizante resulta sobre todo evidente en el ámbito de la plástica funeraria. En la gran escultura se siguen modelos formales de clara raigambre griega (BLANCO, 1960; LANGLOTZ, 1966; CHAPA, 1985 y 1986). Hemos de situar esta moda en el contexto de la élite que desde el siglo VI constituyen las clases que controlan el comercio con griegos y púnicos. Coincide es-

(1) $\mathrm{N}^{\circ}$ inv. 17.943. Inédito. Sobre los vasos recortados y reutilizados en el mundo ibérico cf. OLMOS en PAGE (1984, 275).

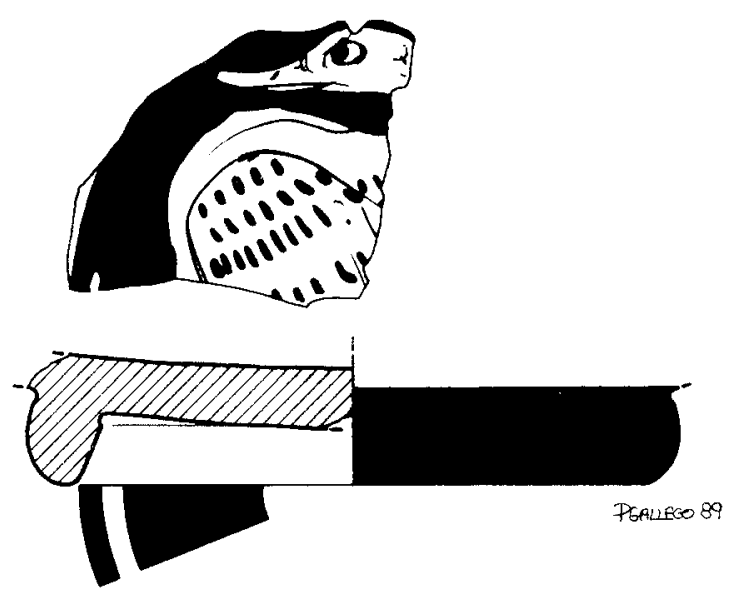

Fig. 2.

ta época con la introducción del alfabeto o semisilabario ibérico, de claro influjo colonial, cuya expansión se explica seguramente por motivaciones comerciales (DE HOZ, 1983). En el área de Elche y su entorno documentamos una amplia demanda de esta gran escultura, con un repertorio característico del mundo funerario de tradición aristocrática: junto con los animales fabulosos orientalizantes - como el grifo o la esfinge psicopompa- propios del arcaismo griego (BLANCO, 1960, lám. 30b; CHAPA, 1986, f. 4,2 (grifo); f. 6,5 (esfinge); RAMOS FERNANDEZ, 1987, 683-4, lám. 3, (grifo); MARIN CEBALLOS, 1987, 65, 66: esfinge, siglo IV) hallamos ya en un segundo momento - siglo IV - una escultura antropomórfica con guerreros -seguramente en el esquema heroizador de monomaquias o certámenes individuales- (RAMOS FOLQUÉS, 1950b; BLANCO, 1960, lám. 25; GARCIA y BELLIDO, 1980, figs. 52-54; OLMOS, 1986, f. 5) o la representación animalística, ahora próxima al hombre y desprovista de los rasgos fabulosos, del caballo enjaezado (CHAPA, 1986, 100102). Todas ellas son imágenes características del ámbito funerario. Gozará de una cierta popularidad la representación del toro, que se ha asociado en la cercana necrópolis de Cabezo Lucero a cultos funerarios en torno al agua y la fecundidad (CHAPA, 1986, 90; RAMOS FERNANDEZ, 1987, lám. 4; LLOBREGAT, 1981, 141-164). Si, en un primer momento, hemos de pensar en unos artesanos de origen griego que introducen las técnicas del trabajo de la piedra y los motivos arcaicos indicados, se han rastreado elementos formales e iconográficos púnicos en algún caso significativo, como en la esfinge 
psicopompa del Parque de Elche sobre la que cabalga un pequeño personaje. Precede al grupo una figurita femenina que recoge y cruza sus alas delante del cuerpo, al modo de Tanit (RAMOS FERNANDEZ, 684; MARIN CEBALLOS, 1987, 65-6; DE GRIÑO, 1987) Una flor de loto decora el pecho de esta supuesta Tanit, eco formal de las terracotas púnicas de Ibiza que conocemos bien por el santuario de Es Cuieram con la representación esquemática y acampanada de la diosa arropada en sus propias alas (ALMAGRO GORBEA, M. J., 1980, láms. 102-107).

Es muy probable pues que, desde los primeros momentos, el ibero amalgame influjos formales e iconográficos de los diversos pueblos mediterráneos con los que mantiene unos estrechos contactos comerciales, en especial los griegos - a través de la colonia focea deEmporion-y los púnicos, establecidos desde el siglo VII en Ibiza. Esta dependencia es clara a nivel formal. A nivel de contenido - iqué es lo que realmente acepta e incorpora el ibero?el problema es más complejo. El resultado en todo caso es algo plenamente original, y en ningún modo un calco del panteón semita o griego. En este proceso los elementos foráneos se van integrando a través de unos segmentos sociales muy definidos, la subcultura aristocrática o la élite local que controla el comercio (OLMOS y DE GRIÑNO, 1985, 23 ss).

En la gran escultura ibérica del siglo IV hallamos también la divinidad sentada - se conserva en el Museo de la Alcudia la imagen de una mujer entronizada con un ramillete de adormideras en su mano derecha-, un motivo de amplia raigambre mediterránea (BLANCO, 1960, lám. 24; GARCIA Y BELLIDO, 1980, f. 55). Y en su plasmación formal se muestra sobre todo muy fuertemente helenizada la famosa Dama de Elche, tradicional paradigma del arte ibérico (GARCIA Y BELLIDO, 1980, 45-52, ff. 56-59; IDEM, 1943, b).

Se trata de un busto que en el ámbito de la gran escultura en piedra se presentaba hasta ahora con características aisladas pero que, gracias a un reciente hallazgo similar en Cabezo Lucero -necrópolis no muy lejana al yacimiento de Elche- podemos comprender hoy mejor (LLOBREGAT, 1989). Son dos los tipos escultóricos fundamentales que utiliza el ibero para la representación femenina en piedra: la mujer sentada, que en su función de señora suponemos que responde generalmente a la iconografía de la diosa o de la mujer heroizada, y la mujer de pie, interpretable como una oferente. En esta ti- pología binaria, perfecta en sí misma -el que ofrece, se muestra activo y solícito, de pie; el que recibe, debe aguardar sentado y solemne- parecía que no tendrían cabida otras posibilidades que se pudieran integrar en un sencillo sistema iconológico de oposiciones. Y se discutió durante mucho tiempo, sobre todo tras el descubrimiento de la Dama sedente de Baza (Granada) - la peculiar iconografía del busto de Elche. Hoy sabemos - lo que sin esta formulación tan precisa habian ya certeramente sospechado E. Kukhan y A. Blanco-que esta Dama no correspondía a ninguno de los dos modelos (KUKAHN, 1957, 3-14; BLANCO, 116, lám. 22). En las Damas de Elche y de Cabezo Lucero, verdaderos bustos, se concibió a la diosa como una epifanía o manifestación, con el velo o manto sagrado enmarcando el rostro. Se trata probablemente de un ánodos, esto es, una representación del instante en que la divinidad ctonia surge de la tierra para mostrarse, ricamente engalanada, ante los hombres. La oposición binaria, pues, no se situaria aquí tanto en la contraposición mujer sentada (oferente)/mujer de pie (divinidad que acoge) como en otra oposición situada ya en el mismo ámbito divino: manifestación pasiva de la mujer, en la plenitud solemne de lo que es - divinidad sentada - frente a la diosa in fieri, en su devenir y en su desvelación, en su tránsito. La cerámica de Elche, que enseguida veremos, nos insistirá precisamenhte en este aspecto dinámico. Esta lectura globalizadora -Dama de Elche, en piedra; bustos femeninos brotando, en un esquema de tránsito, en cerámica- nos abre una nueva vertiente iconológica: es capaz de explicar internamente, dentro de la propia estructura religiosa ibérica, lo que hasta ahora no habíamos visto, preocupados excesivamente por los hipotéticos modelos foráneos, helenizantes o púnicos de la famosa escultura.

En el caso de la Dama de Cabezo Lucero, hallada en las excavaciones hispanofrancesas en el mes de septiembre de 1987, el contexto es funerario. La Dama de Elche se descubrió casualmente, como se sabe, en el año 1897 en la Alcudia. Sabemos que estaba protegida, cuidadosamente, con losas de piedra (RAMOS FOLQUÉS, 1944, 254; IDEM, 1945). Pero en las circunstancias, casuales y antiguas, del hallazgo no quedó definido ni excluido con claridad el contexto funerario, que suponemos, por verosimilitud, tuvo en su origen. Pudo incluso, como toda divinidad, poseer una doble vertiente ambigua, igualmente justificable en el ámbito de la vida que en el contexto de la muerte. El enigmático agujero 
en su torso se concibió para ocultar en él, en el propio cuerpo protector de la diosa, algo muy íntimo. Al descubrirse en 1971 la Dama de Baza, se comprendió mejor esta función de la divinidad como receptáculo o como urna: el costado derecho de la Dama de Baza, hueco, recibió las cenizas del difunto. Es aquí la metáfora, en piedra, del seno materno (GARCIA Y BELLIDO, 1980, 52-56; PRESEDO, 1973; CABRERA y DE GRIÑO, 1986, 193-203). También en la Necrópolis del actual Parque de Elche se halló una escultura de toro, ahuecada en su interior probablemente para servir de urna cineraria. Así lo interpreta certeramente el investigador de esta necrópolis (RAMOS, 1987, 684, ff. 4 a-b). Es el toro una manifestación teriomórfica de la divinidad, de cuyo símbolo gustaron tanto los iberos (CHAPA, 1985, 87-99). No sabemos en cambio, con certidumbre, el carácter de las ofrendas que se ocultaran en el agujero del torso de la Dama de Elche, una imagen de diosa que con su propio cuerpo interviene para acoger aquello que le confía el hombre. Estos presupuestos nos permitirán comprender mucho mejor las frecuentes representaciones del surgimiento de la cabeza femenina entre las flores en la cerámica de los siglos siguientes, ya en la Elche ibero-helenística y romana.

\section{LA CERAMICA}

Los parágrafos precedentes han debido servir para introducirnos en el florecimiento económico del área de Elche en su relación con el mundo mediterráneo. Y también para situarnos en la situación paradójica de la cerámica ibérica, que florece iconográficamente sólo en un momento posterior, tras el auge de la gran escultura de los siglos VI al IV a.C. Ya hemos aludido antes a los condicionantes y a su probable reflejo en el mundo artesanal, en el conservadurismo técnico de la cerámica pintada ibérica.

La cerámica figurada de Elche se asocia por forma, estilo y repertorio iconográfico a un área mucho más amplia que abarca zonas de Alicante y del interior de Murcia: podemos mantener aquí la cómoda denominación de Elche-Archena para este amplio grupo en el que se incluye una zona geográfica del Sureste con características comunes. Aunque nos vamos a centrar prioritariamente ahora en la cerámica de la Alcudia de Elche, sin embargo aludiremos incidentalmente a ejemplos de otros yacimientos de este grupo que nos servirán de contraste.
Frente a lo que ocurre con el estudio de la cerámica griega o suritálica, en el caso ibérico apenas se han realizado estudios de pintores, grupos o talleres, ni análisis pormenorizados sobre las variantes de la decoración ornamental (ELVIRA, 1979: Liria; RAMOS FERNANDEZ, 1982: Elche). Es éste un estudio que deberá desarrollarse en el futuro como paso previo a una sistematización del conocimiento de la actividad artesanal en los diferentes talleres locales. Sólo así se podrá intentar entonces el precisar cronologías - hoy aún excesivamente genéricas y amplias-, así como conocer la dependencia de unos artesanos con respecto a otros y con los mismos talleres. Ya en un segundo momento, habrán de establecerse los posibles stémmata de talleres y artesanos para indagar, en consecuencia, en los sistemas de producción. Simultáneamente será preciso estudiar las áreas de difusión, de expansión comercial, en su relación con la competencia del mercado, etc.: el estudio hasta aquí prioritariamente cerámico deberá enlazar en el futuro con un análisis de distribución del territorio y, más ampliamente, de arqueología espacial (DOMINGUEZ MONEDERO, 1984).

Dada la situación actual de nuestros conocimientos omitiremos pues aquí tanto cuestiones de cronología como de atribuciones a manos individuales, enmarcando esta cerámica de una manera genérica en lo que venimos llamando convencionalmente - y sólo como enmarque cronológico- la época helenística de Elche: coincide este período con el florecimiento de la cerámica figurada local (RAMOS FERNANDEZ, 1987, 693-4: periodización). En épocas anteriores - siglos V y IV a. de C.- la decoración de esta cerámica se reduce a un repertorio de motivos geométricos de círculos y de bandas, una producción monótona que no entra en competencia con las importaciones áticas (PERICOT, ff. 101, 131, 142, 143, etc.; NORDSTRÖM, 1973, 103-107).

No podemos aquí ya evadirnos del problema contextual que plantea esta cerámica: aparentemente la mayor parte de la iconografía que veremos apuntaría, como en el caso de las esculturas, al ámbito de la muerte. Cerámica de otros yacimientos con temas muy similares a los de Elche la encontramos en contextos funerarios. Por ejemplo, en Archena. Pero para los vasos de un yacimiento como la Alcudia de Elche hemos de aceptar una procedencia mayoritaria del hábitat. Incide en ello también la tipología de las principales formas que apuntan al ámbito de la vida, como son las grandes tinajas con 
tapadera, donde - conjeturalmente - se almacenarían diferentes sólidos, como el grano (PERICOT, 1979, 78, f. 98).

Aquí el problema de la relación entre iconografía y contexto no es muy diferente a la de la cerámica ática, con una imaginería ambigua y con temas que pueden a la vez comprenderse desde el ámbito de la vida o de la muerte. En el caso de la cerámica de Elche la indiferencia o ubicuidad contextual de las imágenes -en hábitat o en necrópolis- podrá ser ya por sí misma un primer indicio para su interpretación. No son, pues, vasos concebidos ex professo y exclusivamente para la muerte, como la gran cerámica suritálica, y en especial la apulia (LOHMANN, 1979).

Una cualidad de la imagen en determinadas culturas de la antigüedad como la ibérica es, ante todo, su carácter o función polivalente. Su significado, si la consideramos aislada y en abstracto, es incompleto. Se perfila tan sólo dentro del contexto y en la situación compleja de todo aquél que se relaciona con ella: el que la encarga, quien la realiza o quien la transmite (MARCADÉ, 1985, 27-39; BIANCHI BANDINELLI, 1961, 43; OLMOS, 1987, 21-42, para el mundo ibérico). No debemos olvidar que el pintor trabaja dentro del marco de la sociedad que, expresa o indirectamente, demanda sus productos y es en este diálogo, tácito o abierto, en el que las obras adquieren un significado más concreto. Veremos algún vaso realizado para una demanda cultural específica, como en un complejo cerno de libaciones, donde podremos hoy leer, mejor que en otros casos, esta relación estrecha entre creación, imagen y uso (cf. infra).

Por lo demás, no es un caso aislado éste de Elche en el mundo peninsular español: también, por ejemplo, encontramos con profusión en Numancia vasos aparentemente de iconografía funeraria en el propio hábitat urbano, como toda la serie polícroma (OLMOS, 1986). Vida y muerte se entrelazan continuamente en el pensamiento antiguo, coexisten y no parece que lo hagan forzadamente. Es en la sociedad moderna, que se refugia en la seguridad aparente de la vida, donde se niega la existencia de la muerte, segregada radicalmente de nuestra cotidianeidad (ARIES, 1977).

\section{LOS TIPOS ICONOGRÁFICOS: FLORES Y ANIMALES}

Se ha insistido en la existencia de tres tipos fundamentales de temas: el floral, el animalístico y el rostro femenino de frente, en el esquema de la llamada 'Pepona'. Decoran éstos la mayoría de los vasos de la Alcudia del período ibero-helenístico. Veremos también otros temas aislados que intentaremos integrar en una estructura coherente donde por complementariedad adquieran, unos y otros, un mayor sentido. Vamos, pues, a ensayar la creación de un paradigma comprensivo que contrastaremos con los ejemplos concretos, considerados como realizaciones individuales del sistema.

El motivo central que unifica la práctica totalidad de la cerámica de Elche es la imaginería ctónica, es decir la representación de aquello que brota de la tierra: el ánodos de la naturaleza en sus manifestaciones multiformes (BÉRARD, 1974). Por otra parte, frente al grupo de Liria, en Valencia, con imágenes narrativas y a veces de fiestas colectivas (PERICOT, 1979, 143-187, figs. 198-285; BALLESTER TORMO et ALII, 1954, passim) la iconografía del grupo de Elche es ante todo marcadamente simbólica, y sólo secundariamente ritual. Es decir, las imágenes sugieren, remiten directamente a símbolos, se esconden bajo ellos y tan sólo en casos aislados pueden además reflejar un ritual. Veremos cómo a veces los ejemplos de este posible ritual podrán, en una mayor medida, comprenderse también como realizaciones del paradigma más general (PERICOT, 1979, fig. 154; BLANCO, 1960, lám. 36). Este paradigma habrá de establecerse también sincrónica y diacrónicamente: los precedentes figurativos de la gran escultura han podido configurar una parte importante de este modelo.

La iconografía del grupo de Elche muestra ante todo un mundo abigarrado y en movimiento, in fie$r i$, dinámico. La acción es un ingrediente esencial de este universo de imágenes. La vegetación es exuberante y se combina complementando o sustituyendo a las representaciones animales o humanas: tiene aquélla una entidad propia, un significado en sí misma. No es mera ornamentación que cubre el vaso, sino ante todo vegetación viva y fecunda, en el sentido griego de $\varphi v \tau \tilde{\alpha}$, como naturaleza engrendradora. Se integra pues plenamente en la representación simbólica que enseguida trataremos de definir. Los tallos florales brotan invadiendo el campo decorativo y se resuelven en volutas o en flores secun- 
darias. Muchas veces envuelven a las figuras animales o humanas; enmarcan a estas figuras en su bro$\operatorname{tar}$ (PERICOT, 1979, figs. 92, 95-97, 100, 105-108, $110,114-5,119,150)$. Son expresión y símbolo del propio ánodos divino. Pero poseen en ellas mismas entidad propia: pueden cubrir metopas o zonas enteras. En este último caso se refuerza su valor de símbolo: la vegetación floral es aquí sustituto -a veces, indicio o señal-del ánodos animal o antropomórfico (PERICOT, 1979, f. 110).

El motivo animalístico se concibe frecuentemente como un prótomo que brota de la tierra, generalmente entre tallos florales (PERICOT, 1979, figs. 105-114, 119-20, 125, etc.). Pero en muchas ocasiones se represena al animal completo (PERICOT, 1979, figs. 100, 106-108, etc.). Hay dos variantes fundamentales: el ave de alargado pico y el llamado carnicero. No preocupa en exceso la representación realista del mundo animal, sino su valor simbólico. Por eso, en el caso del ave, no podemos definir con seguridad si se trata de un águila o de otro rapaz: es una representación ideal, genérica (NORDSTRÖM, 1973, 155; IDEM, 1968, 97-120).

En la cerámica del grupo de Elche se reducen a un puñado de ejemplos aquellas imágenes de aves que podríamos clasificar taxonómicamente en una especie concreta (NORDSTRÖN, 1968, 109-110). También el llamado 'carnicero' une a las fauces de lobo rasgos ambiguos, como las melenas, que apuntarían también a un león: no se pretende tanto la descripción realista de un animal cuanto la idea o sentimiento - de terror aquí, de poder-que suscita. Al aludir a un ámbito de tránsito, la ambigüedad caracteriza a este ser de entre dos mundos. Asimismo funciona como símbolo de la naturaleza del mar un pez genérico (NORDSTRÖM, 1973, 160-1). Pero el pez no tiene reservado en el campo del vaso un espacio concreto entre los pobladores del agua. Se entremezcla con los animales de la tierra y del aire. Símbolo de la tierra es el conejo - que aquí sí responde a una concepción marcadamente más realista y próxima al ibero-y, su oponente, la serpiente, asociados con frecuencia (NORDSTRÖM, 1973, 151: conejo; 154: serpiente; PERICOT, 1979, f. 164: asociación de ambos). Aquélla se estiliza en un meandro curvilíneo, convirtiéndose en ocasiones en enmarque decorativo: en la gran jarra del $\mathrm{Mu}$ seo Municipal de Elche la hallamos, como ser vivo, en manos de una de las diosas aladas o entre los animales, y a su vez como esquema decorativo enmarcando lateralmente la escena (PERICOT, 1979, fig.

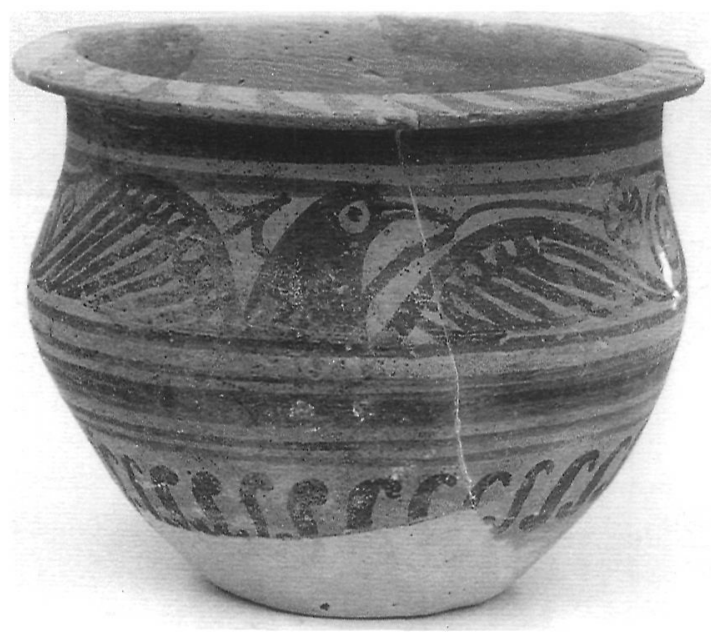

Fig. 3.

94; RAMOS FOLQUÉS, 1943, figs. 8-10). Los límites entre lo decorativo y lo simbólico una vez más son aquí ambiguos.

La concepción del espacio y de las mismas figuras son analíticas: se acentúan de forma expresionista en éstas sus rasgos más significativos, que se reservarán en el fondo claro de la arcilla. Así, en el ave, las garras, el ojo redondo y el largo pico. Las alas, como en todo arte mostrativo, suelen dibujarse de frente ante el espectador (PERICOT, 1979, figs. 95,100 , etc). Y en el carnicero, se subrayan los rasgos apotropaicos: unas fauces inmensas, de las que surge la lengua desmesurada, con la doble fila de alargados dientes, las garras $y$, sobre el vientre, la representación irreal y geometrizada de las costillas: es el prototipo del animal hambriento y devorador (PERICOT, 1979, figs. 195-108, 126).

Los tallos florales envuelven a los animales, de manera que éstos, sobre todo en las representaciones de prótomos, brotan de aquéllos (OBERMAIER, y HEISS, 1929, 56 ss. lám. 12; GARCIA Y BELLIDO, 1976, figs. 549-551, 553-4 (Archena); OLMOS, 1987, 25-28, f. 4). De este modo se refleja el impulso de la naturaleza fecundante y engendradora. Pero muchas veces - como en el caso aquí de las aves - el animal se identifica con la misma flor de la que nace picando en ella (Ex. gr., PERICOT, 1979, figs. 95, 119, 159 etc.; GARCIA Y BELLIDO, 1976, f. 554: Archena). Es un motivo que encontramos en otras cerámicas mediterráneas, como la suritálica del siglo IV y la helenística, la calena (2). Nos referimos a él de nuevo. 
La representación combinada de los animales refleja un mundo vital, de opuestos. No expresan una concepción de una naturaleza estática. En este sentido muestran una concepción arcaica del mundo, con fuerzas contrapuestas que escapan al control humano. Es cierto que apenas hay un enfrentamiento directo entre estos animales, sino latente: desbordan amenazas, inspiran terror, se persiguen pero nunca se devoran y raramente se atacan mutuamente. En este hecho hay también un condicionante de la propia concepción pictórica: los pintores ibéricos representan sobre todo planos $\mathrm{y}$, en mucha menor medida, volúmenes. Aceptan la cerámica como superficie y no se preocupan por la representación ilusionista de la perspectiva. Cuando tienen ocasión de representar una escena en profundidad, como en el vaso de la diosa con los dos caballos de frente, lo resuelven descomponiendo practicamente el volumen en un plano único (PERICOT, 1979, f. 109, LLOBREGAT, 1972, lám. 14, NORDSTRÖM, 1973,260, f. 51). Por ello son muy escasas aquellas representaciones en que dos cuerpos se superponen. Se reducen casi a la del motivo inevitable del jinete montado a caballo. Es éste un esquema que crea ciertas dificultades al pintor pues tiene que representar a la vez la pierna del jinete y el cuerpo del caballo: suele adoptar la solución de reservar en claro el elemento más definido e individualizado de ambos, la pierna, sobre la silueta negra del animal (PERICOT, 1979, f. 166). Pero si la superposición de dos figuras se puede evitar, se evita (PERICOT, 1979, f. 126). Ello acentúa la visión analítica de esta cerámica: cada animal permanece encerrado en su propia esfera de ser. Coexiste con los demás. La naturaleza se expresa como una yuxtaposición infinita de estas individualidades. El orden, dentro de la multiplicidad aparente, surge precisamente de esta violencia desbordada que arranca de cada individuo. Es un cosmos creado por la tensión entre opuestos.

\section{LOS TIPOS ICONOGRAFICOS: LA REPRESENTACION HUMANA}

La representación humana es la tercera variable de este universo de iconográfico de Elche. Predomina aquí la representación de la mujer. Pero en ningún modo refleja el mundo femenino ibérico real.

(2) Cf. la lebeta nupcial de Paestum del Museo Arqueológico Nacional, n. ${ }^{\circ}$ 11.445; TRENDALL, 1987, 128, lám. 76.
Apenas hallamos un atisbo de su vida cotidiana, ni siquiera en su manifestación festiva o cultual. Como posible excepción -y muy dudosa- debemos citar el fragmento de un vaso de plástico de la Alcudia de Elche - posiblemente un frasco de perfumes, realizado a molde y seguidamente pintadocon dos figuras recostadas en un lecho (RAMOS FOLQUÉS, 1951, 195-200, lám. 30). El busto de la derecha sostiene una copa en una mano mientras que su brazo derecho se alza como si fuera a abrazar por el hombro al compañero. Del rostro no se conserva más que la parte inferior, con el cuello, y podría tratarse de un rostro de frente y femenino, cuya frontalidad acentuaría aquí plásticamente el relieve mismo del vaso. De ser así - no es del todo segurotendríamos una representación de un simposio con una mujer, lo que nos aproximaría al mundo itálico. Tanto la técnica del vaso como su temática indican una imitación aislada y resulta por lo tanto muy problemático interpretar la escena más allá de la materialidad de lo que vemos.

Acaso con la excepción de este ejemplo fragmentario y dudoso, que queda abierto a ulteriores análisis, el universo femenino de Elche se proyecta siempre en el paradigma divino, el único representado en estas cerámicas. La dualidad hombre-mujer se expresa prácticamente sólo bajo esta relación: divinidad femenina, por un lado; varón, en representaciones generalmente heroicas, por otro. Es pues, la imagen de la diosa, no la de la mujer mortal, la que aparece como cohesivo social en este universo figurativo de la sociedad ibérica.

Dentro de esta representación femenina hallamos aquí la misma polaridad que vimos en el mundo animal: sea en el esquema de prótomo, brotando como una flor, o como figura completa, esto es en la realización de haber brotado, concebida como efigie.

El busto que surge lo hace generalmente de frente, pero alterna también con representaciones de perfil (FERNANDEZ DE AVILES 1946, 162-172; PERICOT 1979, 115, 154: rostro de perfil, 127, 138, 151 (frontal); GARCIA Y BELLIDO 1976, f. 572). El rostro frontal - la llamada imagen de la 'Pepona ${ }^{6}$ - se relaciona directamente con el espectador: es otro modo de expresión dinámica — vaso y poseedor - comparable al que establecen los animales entre sí. Aquí lo establece el dios con el hombre: con el ibero, con nosotros. A través de esta imagen antropomórfica, pero grotesca y mostruosa, el ibero mismo que mira y se mira en el vaso se incorpo- 


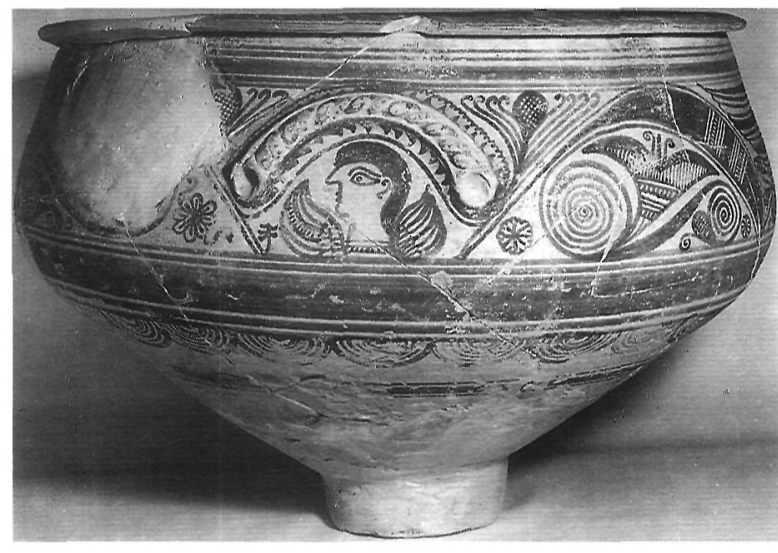

Fig. 4.

ra a este universo de la naturaleza abigarrada (VERNANT, 1981, 141-5; FRONTISI-DUCROUX, 1984, 147-161; EADEM, 1987, 197-213). Cumple pues una función mediadora — no sólo social, sino cósmicael rostro frontal de la diosa. Tras la paradoja de este lenguaje arcaico puede sin embargo el ibero participar en un sentimiento religioso muy extendido en el Mediterráneo helenístico: frente a las divinidades alejadas y distantes el helenismo acercó los dioses al hombre, los hizo epékooi - es decir, prontos a escucharles- y acentuó en sus representaciones el pathos y el sentimiento. Estas máscaras ibéricas de los rostros frontales participan de esta comunicación mediterránea que conocieron también en sus imágenes los púnicos de Ibiza (M. J. ALMAGRO GORBEA, 1980, ex. gr., lám. 68-69) y los ampuritanos ante la estatua en mármol de su dios curador, Asclepio, levemente inclinado para escucharles (GARCIA Y BELLIDO, 1948, II, 130-3).

Iconográficamente en esta imagen ibérica pervive sin embargo la tradición arcaica de la Grogona. En uno de los grandes cálatos de la Alcudia de Elche vemos una precisa adopción formal del viejo motivo helénico: rostro redondo, peinado dividido simétricamente en dos mitades enmarcando la cara, nariz chata, representada en diversos planos horizontales, y el semicírculo de la lengua sonriente, en la característica mueca aprotropaica de la Gorgona. Pero el rostro es a su vez una flor: la barbilla se torna puntiaguda y en ella se indican incluso los sépalos del cáliz (PERICOT, 1979, fig. 127; LLOBREGAT, 1972, lám. 13; GARCIA Y BELLIDO, 1976, figs. 572-3; BLANCO, 1960, lám. 38b). La metamorfosis flor-diosa queda aquí perfectamente definida y con ello la unidad temática del conjunto. La diosa forma parte integramente del todo: es engendrada por la misma naturaleza que preside (3). $\mathrm{Al}$ rostro se le reserva aquí un lugar preferente en el vaso, debajo de las asas del cálato. En realidad las asas estructuralmente son superfluas. Carecen de otra función que la puramente ornamental y simbólica: el arco que dibujan, recoge y acentúa la rotundez del rostro de diosa. Como el templo bajo cuya protección se guarda la imagen sagrada, es éste el lugar más protegido del vaso, en oposición al espacio abierto donde se despliega en su dinamismo la naturaleza. El rostro justifica aquí las asas. No a la inversa. De nuevo nos hallamos ante otro motivo arcaizante, pues esta asociación, frecuente en la cerámica de Elche, es el residuo de una situación más antigua: la posición de la cabeza 'hathórica' bajo las asas se documenta en bandejas de bronce ibéricas del siglo IV, por ejemplo en Baza (Granada) (PRESEDO, 1973, lám. XV, 4). Y, con la antigua sugerencia de Erich Kukahn, podríamos establecer el stemma del motivo a lo largo de la cuenca Mediterránea - sobre todo la oriental-buceando en los siglos protohistóricos (KUKAHN, 1962). Pero no es nuestra intención insistir en el pozo sin fondo de los paralelos y antecedentes, sino más bien en cómo se estructuran los motivos dentro del mundo iberohelenístico de Elche, esto es cómo pueden ser un reflejo dialéctico de su universo ideológico.

En otro de los ejemplos - un gran recipiente de boca abierta, a la manera de un caldero cerámicoel busto se muestra de perfil y alado, también bajo las asas: brotan a ambos lados unos inmensos tallos florales (PERICOT, 1973, f. 115; LLOBREGAT, 1972, XIV; BLANCO, 1960, lám. 37). Es una diosa de larga melena y su cuello, estirado en el brotar, lo adorna un collar. Nos vamos aproximando así a uno de los posibles modelos formales del motivo aquí representado.

Sobre el cuello de una jarra probablemente del taller de Archena podemos comprender el paradigma que proponemos de estas representaciones como ánodos (OLMOS, 1987, 25, fig. 3). La cabeza femenina, de perfil, nace entre flores pero en su brotar eleva levemente el rostro hacia el cielo, en el característico gesto del tòn ouranòn eisideîn que co-

(3) Para esta asociación en el mundo itálico, GILOTTA, 1985, 16 ss; para las relaciones entre el Gorgoneion y la Gran Madre, cf. p. 25 así como la vieja tesis de FROTINGHAM, 1911. 
nocemos bien por las representaciones de los ánodoi áticos y suritálicos, especialmente las de Apulia (KOSSATZ, 1986, 132-134; AELLEN y CAMBITOGLOU, 1986, 147) y en las mismas dracmas ampuritanas - una cabeza femenina entre delfines, elevando el rostro- que por este detalle hemos también de entender como el ánodos marino de una diosa, tal vez Afrodita. Nuestro vaso se halló como ajuar de una tumba de Villaricos, en Almería, una necrópolis ibérica que coexiste junto a una púnica: esto es, un lugar clave para las transacciones comerciales así como punto de encuentro directo entre dos culturas. Es, pues, muy posible que aquí el ibero entre en contacto estrecho con el mundo religioso colonial: el púnico se enterraba con frecuencia con estas imágenes, generalmente a través de los pequeños lécitos áticos de figuras rojas, tan abundantes durante el siglo IV en las necrópolis de Ibiza (OLMOS-DE GRIÑO, 1985, 39-40) ¿Se trata, en este ejemplo de Archena, de un vaso de encargo - un 'bespoken vase' - como he postulado en un reciente estudio, en el que se imita un modelo mediterráneo? (OLMOS, 1987). Queda el problema de la cronología. Las importaciones de este motivo se sitúan en el siglo IV a. de C. y la cerámica de ElcheArchena viene situándose en un momento posterior, lo que dataría nuestro vaso, al menos, en el siglo III: un probable ejemplo de retardación en una área periférica, si es que el influjo no llega a través de las mismas monedas con el ánodos marino. En todo caso, significativo para nuestro discurso iconográfico es también el haber hallado la imagen de la diosa en la misma posición -el cuello de una jarradonde con frecuencia aparecen los prótomos ascendentes de un carnicero o de un ave. En este ejemplo de Villaricos el busto de mujer, como innovación, sustituye a aquéllos. Es decir, en los tres casos se trata de la realización diferente de una idea similar. En el ejemplo del carnicero o el águila es una manifestación teriomórfica del ánodos. En el caso de la mujer, una sustitución antropomórfica, por un probable influjo formal mediterráneo, helénico.

Un reciente hallazgo de la Alcudia (RAMOS FERNANDEZ, 1989), cuya forma muestra reminiscencias de una pequeña cratera aunque es de fecha ya tardía, nos especifica algo más el carácter episódico y cultual del motivo. En el anverso la cabeza femenina brota frontal y gigantesca y el color oscuro de su cuello es un indicio - como si de un tronco o elemento vegetal se tratara- de la metamorfosis, del tránsito. En lugar de picar en una flor, dos aves, casi en actitud heráldica, se acercan a libar junto a los oídos de esta divinidad monumental. Pero es sobre todo un dato clave la representación del reverso en el que dos varones, de perfil y entre serpientes, brotan igualmente de la tierra para contemplar el ánodos de la mujer. Es la primera vez que hallamos la acción de la epifanía acompañada por la contemplación de otros personajes ctonios. Es éste el desarrollo o realización más completa de este sintagma mítico. Posiblemente la imagen, repetida, acaba desarrollando su propia historia, su mitología.

Veamos otros ejemplos de estos estímulos formales en la representación de la divinidad femenina, ahora en su figuración completa, como efigie. En el extremo del panel de una gran ánfora de asas triples - que enmarcan meandros serpentiformes, acentuando el contenido ctónico de la escena - vemos una imagen completa de la diosa como potnia theron, apoyada sobre la punta de los pies y asociada al universo teriomórfico, en torno a ella: agarra con su diestra una de las aves (PERICOT, 1979, figs. 128-129; GARCIA Y BELLIDO, 1976, fig. 546: Archena). No ha dibujado el pintor su brazo izquierdo pues no es narrativamente necesario: basta con que el ave de largo cuello revolotee en derredor, con una rama en su pico, para indicarnos la pertenencia del ave al círculo espacial de la diosa. También pertenecen a su ámbito los peces y el conejo a sus pies, así como las rosetas frontales que, enseguida veremos, son símbolo de su presencia. El detalle arcaizante del vestido nos indica otro probable influjo formal mediterráneo: la diosa viste una túnica con cólpos y apóptygma, ceñido justo bajo el pecho como en la moda italogriega. No conocemos este vestido en el mundo ibérico a través de la representación de sus exvotos. Ello nos indica que se está pensando en un modelo iconográfico foráneo, en una imagen de culto arcaizante, vestida con el prestigio de la moda helénica.

Un nuevo ejemplo de esta iconografía tan influida formalmente por los modelos de raigambre griega es la representación de la llamada potnia hippon, ocupando el panel principal de una gran tinaja ilicitana (PERICOT, 1979, f. 109, LLOBREGAT, 1972, lám. 14; NORDSTRÖM, 1973, 260, f. 51; BLANCO, 1960, lám. 53a). La diosa, aquí alada, se muestra de nuevo bajo el esquema frontal. Extiende sus manos a dos caballos que heráldicamente vuelven su rostro hacia la diosa, expresándose así la pertenencia a su ámbito, su sumisión. No son unos caballos cotidianos, sino sagrados: las gran- 
des alas que arrancan del suelo - una sólo en cada animal se representa desplegada ante nosotros-y su carácter de busto nos sugieren de nuevo un ánodos. La diosa, pues, no surge sola, sino en la compañía de la biga divina. Aunque la parte inferior de su cuerpo se ha perdido, seguramente no estuvo en su origen representada por completo: los cuerpos de los caballos parecen unirse junto a la diosa, como si formaran un cuenco que enmarca y acoge el ánodos divino (4). Ya F. Benoit, que reproduce en un dibujo una reconstrucción de la figura completa de la diosa que considero errónea, adujo paralelos mediterráneos a esta representación, que otros autores han asociado a la Artemis griega (BENOIT, 1953, 211-218, fig. 4; BLAZQUEZ, 1959, 16-18; BLAZQUEZ, 1977, 305, fig. 107). Como paralelos religiosos no explican casi nada si al mismo tiempo no se tratan de comprender internamente. Nos interesará tal vez más la aproximación al proceso imitativo formal: la diosa viste una túnica de mangas cortas que ciñe por un cinturón justo bajo el pecho. Este precisamente es el atuendo propio del auriga en las representaciones griegas y mediterráneas de carros. Nuestro vaso, de nuevo, es una hierofanía, la manifestación dinámica de una diosa que surge del reino infernal en su biga de caballos. Ni siquiera toca las riendas, pues surge sin esfuerzo, atendida por unos caballos solícitos con su señora la diosa. A ella pues le basta - aquí como dea otiosamostrarse.

Tras el análisis de todos estos ejemplos cabe, pues, proponer que la imagen religiosa ibérica adquiere forma y expresión humana bajo el prestigio de la iconografía griega: hemos visto que acepta e integra el motivo mediterráneo de la Gorgona, el motivo - sobre todo popular en el sur de Italiadel rostro asociado a la flor en la metamorfosis de ésta y de aquél bien como diosa de los tallos, como Rankengöttin (STOOP, 1960), que hallamos asociada asimismo sobre el vestido de Tanit en dos terracotas de Ibiza (M.J. ALMAGRO GORBEA, 1980, láms. 68-69). Hemos visto también la adopción de la imagen arcaizante de la diosa con peplo, o de su hierofanía como auriga. Son, probablemente, variaciones o realizaciones particulares de una idea religiosa común que sintetiza y recrea el ibero bajo es-

(4) Cf. los ejemplos en bronce de la llamada época orientalizante de Tartessos, por ej., el bronce 'Carriazo' del M. ${ }^{\circ}$ de Sevilla. BLAZQUEZ, 1975 b, lám. 27. tímulos, en parte griegos o suritálicos, —o púnicospero con fórmulas originales.

De un modo similar en los siglos anteriores vimos la aceptación de un lenguaje plástico helénico en la gran escultura funeraria ibérica. Pero queda la pregunta de hasta qué punto junto a la imagen se introduce o no también un contenido - al menos, una parte del contenido iconológico- o si, por el contrario, se trata solamente de una aportación formal, a modo de un ropaje plástico ajeno con el que viste un pensamiento religioso propio el artista local. Resultaría difícil suponer la introducción ex novo de un motivo sagrado, de una divinidad, foránea y extraña al mundo ibérico, sólo por influjo colonial. Y, más aún, cuando tan amplia aceptación hallará este motivo en la cerámica iberohelenística del Sureste. En nuestra hipotética reconstrucción del proceso hemos de suponer más bien que el lenguaje griego se escoge para expresar un contenido cultural ya preexistente, o latente, en el mundo indígena. La innovación radica en la introducción de la representación antropomórfica, lo que debe considerarse revolucionario en un pensamiento de tradición marcadamente anicónica como es este caso. Pero, a su vez, la introducción de la nueva imagen transforma la anterior estructura iconográfica $\mathrm{y}$, con ello, el mismo contenido religioso precedente. Pues la imagen antropomórfica es, en sí misma, afirmación de un contenido religioso que antes no podía existir como tal. Es decir la imagen, pregnante, crea ella misma mito, lo explicita y lo define con los contornos precisos de la forma. Etiológicamente el proceso no va tanto del mito a su representación como a la inversa, conjugándose en un complejo proceso de gestación en que el uno alimenta al otro y viceversa. Podemos entenderlo pues como un sincretismo dialéctico.

El pequeño cerno, repetidamente estudiado por diversos autores, puede ser un buen ejemplo para sintetizar el tema: se trata de la vieja variante del vaso múltiple, cuyos diversos recipientes une un anillo que comunica el líquido con los otros vasos comunicantes (RAMOS FOLQUÉS, 1966 b; PAGE, 139, f. 22; para los cernos, KOSSATZ, 1985). En nuestro ejemplo de Elche, tres anforitas perforadas podían recoger las diferentes ofrendas líquidas que, a través de un tercer vasito, fluirían finalmente sobre un cuenco. En el interior del cuenco hallamos la imagen de la diosa - su rostro frontal, ricamente adornado con collares y pendientes- que recibe la libación. El ánodos divino es inseparable aquí de 
nuevo del universo animal que la rodea, aves, conejos, peces: el vasito es en sí mismo un microcosmos. El gesto de libar, que en definitiva es verter el líquido sacralizado sobre la tierra, se realiza aquí sobre la misma diosa de la tierra que nos mira - y a la que miramos- de frente. No sabemoś si en los tres vasitos verticales que comunican entre sí a través del anillo de sustentación -igualmente adornados con imágenes de este mundo vegetal y teriomórfico- un único oficiante mezclaría tres líquidos diferentes; o si, más bien, depositaron en ellos sus ofrendas tres personas, como representantes de tres grupos familiares que se unen a través del ritual en la ofrenda. En la habitación donde se halló el cerno se encontró también una botella panzuda, de boca estrecha, para perfumes, y un timiaterio en arcilla, con cabezas frontales realizadas a molde. Se trata, en este último vaso, de un utensilio importado (RAMOS FOLQUÉS, 1966).

La presencia en el hábitat de este conjunto nos plantea de nuevo la pregunta del carácter del culto aquí practicado. Sin ninguna duda estamos en presencia de un ritual ctonio. Es muy posible que este ritual - como en tantos otros lugares del Mediterráneo- revista también una vertiente funeraria. O más aún, como señaló $\mathrm{P}$. Stengel para el mundo griego, que las diferencias entre el culto ctonio y funerario no sean originarias sino sólo secundarias (STENGEL, 1910, 144). Recordemos, en el mundo ateniense, el ritual de las Panspermia, con las ofrendas de semillas a Hermes ctonio durante la fiesta de las Antesterias, el día de las Chytrai, una fiesta en su origen funeraria (KOSSATZ, 1985, 232). Este hipótesis justificaría con nuevos argumentos toda esta imaginería aparentemente funeraria en el habitat de la Alcudia.

Hemos hablado hasta aquí de influjos mediterráneos helenizantes, en una determinada interpretación de formas, de gestos, y hasta de objetos de culto. Pero también es cierto que un similar discurso comparativo podría establecerse en relación con el mundo púnico. En el apartado historiográfico apuntábamos a algunas lecturas propuestas ya en este sentido: se ha visto repetidamente la imagen de la diosa Tanit en determindas representaciones cerámicas ilicitanas (RAMOS FOLQUÉS, 1953, 330; BLAZQUEZ, 1975, 30-38. s.v. Artarté; MARIN CEBALLOS, 1987). Aun siendo escéptico, como vengo diciendo, ante el modo como se han propuesto algunas de estas adecuaciones religiosas en cierta medida mecanicistas no cabe negar la realidad del gran influjo púnico en la transmisión de muchos de los motivos helenizantes o semitas al mundo ibérico. El ejemplo de Tanit es uno de ellos. En la Elche del período helenístico hallamos, como en muchos otros yacimientos de la costa ibérica, los conocidos timiaterios en arcilla, importados, que representan el busto de una diosa de la fecundidad, ctonia, coronada con espigas y frutos. En el ámbito griego esa diosa ctonia sería identificable con una divinidad del círculo de Deméter. En el mundo púnico, que expandió comercialmente esta imagen en el Mediterráneo occidental, con Tanit. Creo que en el contexto ilicitano esta imagen importada se integra perfectamente en el ámbito de la divinidad local ctonia que venimos analizando (5). El conjunto de los elementos iconográficos son comunes: busto/ánodos, frontalidad, aves, asociación directa con la fecundidad de la naturaleza, etc. Hubo posiblemente un fenómeno habitual de sincretismo, donde el prestigio de la importación puede actuar incluso como un estímulo para la creación y auge de la imagen local. No es ésta una intrusión nueva por parte del mundo púnico. Ya en la gran escultura hemos señalado la figuración de Tanit en el grupo de la esfinge psicopompa (MARIN CEBALLOS, 1987).

Otras representaciones cerámicas pueden responder a este mismo influjo formal: el gran ánfora del Museo Municipal de Elche lo preside la figura de la diosa, de cuerpo entero y alada, acompañada de rosetas y asociada a una vegetación inmensa que brota de ella (PERICOT, 1979, fig. 150; GARCIA Y BELLIDO, 1976, fig. 573; BLANCO, 1960, lám. 34 b). Lleva un vestido acampanado, que recuerda la estructura de las terracotas púnicas y, como aquéllas, no tiene pies. Decora su vestido una flor de cuatro pétalos, que en la cerámica de Elche sugerirá, como símbolo aislado, la presencia de la diosa en muchos otros ejemplos (PERICOT, 1979, figs. 103, 119: bajo las asas, 165, etc.; KUKAHN, 1962).

En el cuello de una gran jarra del Museo Municipal de Elche tenemos la representación de dos personajes alados afrontados entre animales (RAMOS FOLQUÉS, 1943; BLANCO, lám. 34 a). Se han asociado estas figuras con la Tanit púnica. En el vaso hay dos zonas perfectamente definidas, el cuello y la panza, cuya separación acentúa una moldura.

(5) Quemaperfumes de Elche en el Museo Arqueológico Nacional de Madrid no inv. 17.635 (1986/51/5) (tipo diosa turriforme; n. ${ }^{\circ}$ inv. $17.652(1986 / 151 / 69)$ (tipo dea frugifera). 


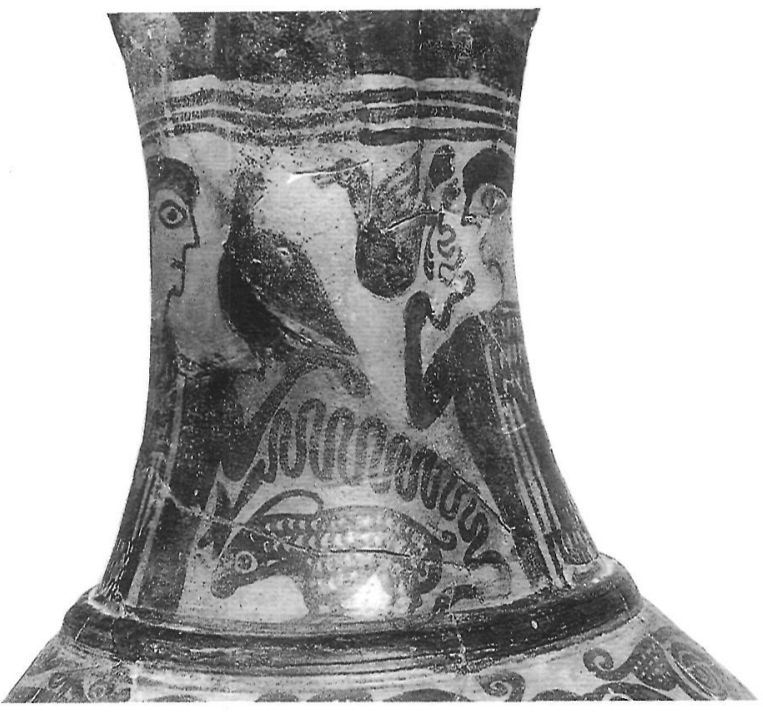

Fig. 5.a y $5 b$.

Como en los demás vasos de Elche de lectura horizontal, también aquí, en lectura vertical, una y otra zona iconograficamente se complementan. La zona inferior muestra una hierofanía animal, dos grandes aves afrontadas entre tallos florales. Entre ambas, sobre el ala de una de ellas, una serpiente. En el friso superior la teofanía es antropomórfica y ofrece la peculiaridad de presentar, como caso único en Elche, la contraposición casi simétrica de dos figuras aladas. Son el reflejo correspondiente, como divinidades femeninas, de la contraposición animal de la panza. Ambas mujeres se asocian estrechamente a un ave. Se posa el pájaro de la izquierda sobre la mano divina. El personaje de la derecha en cambio agarra de su extremo una serpiente. Una gran serpiente envuelve también al conejo agazapado en el suelo, entre ambas mujeres. Los símbolos corresponden perfectamente con los de aquellas otras representaciones que preside una sola figura antropomórfica. Si aceptamos el paradigma conocido, hemos de suponer que esta representación de dos personajes se integra también en la misma esfera religiosa de los demás vasos. Pero aquí la presencia de la divinidad ctonia se entiende como confrontación, como diversidad, como tensión de opuestos y no como diosa o fuerza única, como en el cerno. Son, creo, ensayos diversos ante una incipiente figuración humana de lo sagrado: la ambigüedad parece pues inevitable.

Este vaso nos enseña además la asociación tan estrecha del personaje alado con el animal. Los lí-

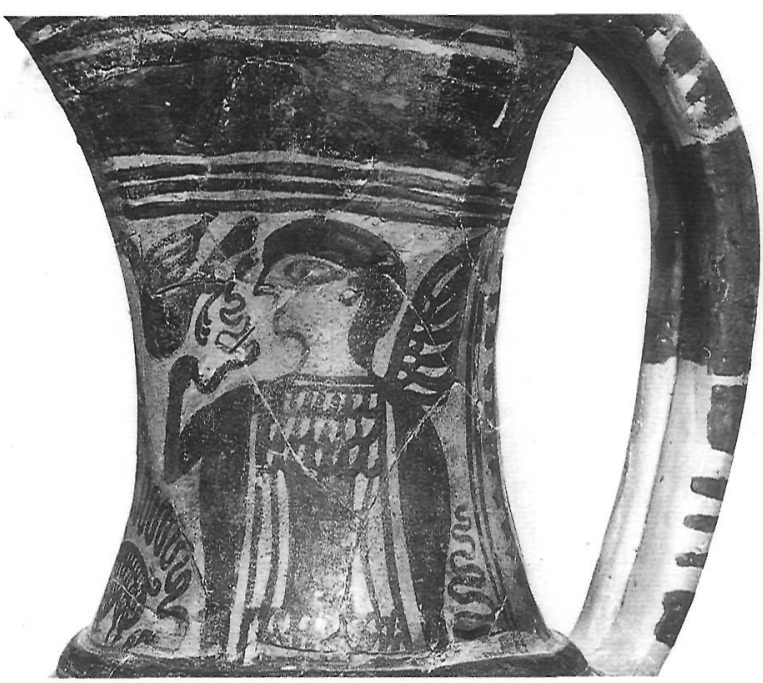

mites reales entre los diferentes tipos de símbolos no están muy claros. Una misma idea puede reflejarse bajo diferentes formas. Y, a la inversa, el símbolo sólo adquiere su significado preciso en su relación contextual. La diosa es unas veces, ella misma, vegetación, como en la gran ánfora del Museo Municipal de Elche. Y otras, a la vez, mundo animal: en el vaso de las 'Peponas', bajo las asas, el prótomo de carnicero brota justo al lado de la diosa como si ésta y aquél formaran parte de una amalgama inseparable (LLOBREGAT, 1972, lám. XIII). Decimos que los símbolos se codefinen mutuamente: una vez más expresan aquí la multiformidad fecunda y contradictoria de la naturaleza.

Pero la misma metamorfosis puede tener aspectos múltiples. No se reduce a la transformación de la flor en rostro humano que vimos más atrás, en el caso de la 'Pepona-Gorgona'. En el fragmento de un gran vaso ibérico, procedente de Moratalla, en el interior de Murcia y hoy en el Museo arqueológico de esta ciudad, tenemos de nuevo el motivo de la hierofanía de la dioșa, representada de frente (LILLO CARPIO, 1983). Eleva ambos brazos que rematan no en manos humanas sino en prótomos de lobo, reflejo de su transformación teriomórfica. Unas cabezas de lobo amenazante enmarcan a ambos lados el panel con la aparición de la diosa y acentúan su pertenencia a este mundo animal, un reino de nuevo ambiguo, de tránsito, como ambigua es toda metamorfosis. 


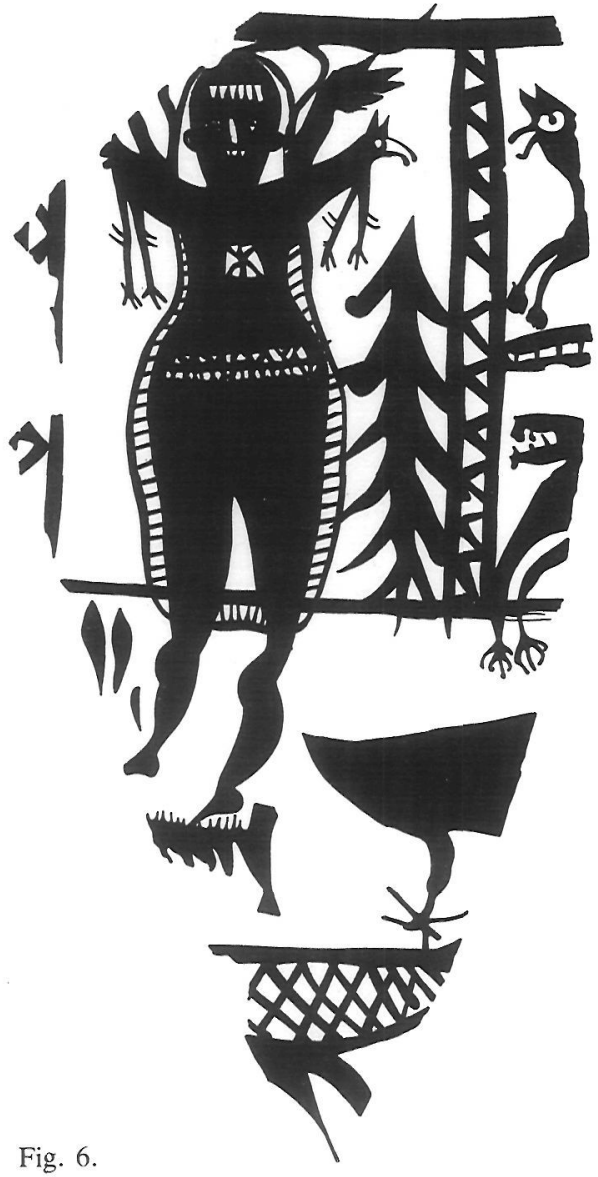

Ya hemos apuntado que la imagen de la diosa se sustituye muchas veces por su símbolo vegetal. Como vió certeramente Erich Kukahn, la roseta es su expresión simbólica (KUKAHN, 1962). Se asocia continuamente a la epifanía de la diosa. Ocupa en ocasiones la posición privilegiada de la divinidad, bajo el arco de las asas. Al igual que la imagen del rostro ésta a veces va sola, pero otras veces es una roseta alada (PERICOT, 1979, figs. 100, 112, 126, 148). Las alas expresan el carácter sobrenatural y sagrado de todas estas imágenes. En otras ocasiones las alas se esquematizan o sustituyen por volutas a ambos lados de la flor, no sabemos si como una sugerencia simultánea de serpientes (PERICOT, 1979, figs. 115-6, 124, 149; BLANCO, 1960, lám. 37 b).

Como en la diosa, la epifanía de la roseta se vincula también al exuberante mundo de las ramas y al teriomórfico: un lobo con las fauces enormemente abiertas protege el asa bajo la que nace la flor divina, en el cálato anteriormente descrito (LLOBRE-

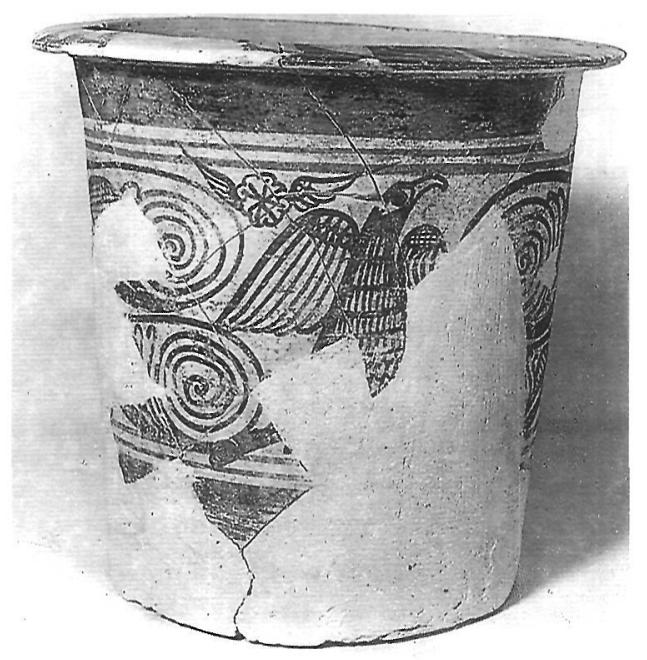

Fig. 7.

GAT, 1972, lám. XIII). En el gran vaso abierto de la Alcudia, que ya hemos estudiado en relación con la cabeza alada bajo las asas, se desarrolla en uno de los paneles el ánodos de un águila y, detrás, el surgimiento de una roseta con alas-volutas (PERICOT, 1973, f. 115; LLOBREGAT, 1972, XIV; BLANCO, 1960, lám. 37). Hay en este vaso —como en el cálato del águila ascendente y la roseta aladauna insistencia, una hipercaracterización o énfasis simbólico que refuerza las manifestaciones múltiples de una misma idea.

La mayoría de estos vasos deberán estudiarse, pues, en sus diferentes esquemas sustitutorios. Las combinaciones diversas de elementos constituyen las variantes en la realización particular del paradigma.

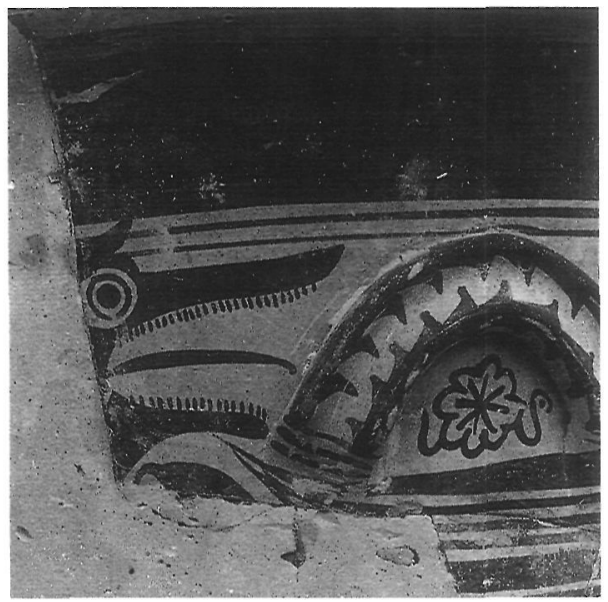

Fig. 8. 
Establecido éste - lo que requerirá un trabajo minucioso previo de catalogación- (6) podremos comprender mejor las aparentes excepciones al paradigma.

Tal es el caso de los vasos que veremos en el apartado siguiente y del fragmento de gran tinaja de la Alcudia con la procesión de los varones que caminan hacia la izquierda con sendas ramas en las manos (PERICOT, 1979, f. 153). Visten túnica corta ceñida a la cintura. Acompañan su marcha, alternando entre ellos, conejos. Estamos ante una escena cultual, uno de los pocos motivos claramente asociables a un rito en esta cerámica que se centra prioritariamente en la expresión del símbolo. En un cálato de la Alcudia es la misma diosa quien sostiene en sus manos las ramas rituales (PERICOT, 1979, f. 154; BLANCO, 1960, lám. 36). La escena humana, pues, se justificaría como una imitatio dei, es decir, como la fiesta de los hombres que recuerdan el ánodos o nacimiento sagrado en la marcha ritual.

\section{VASOS DEL HOMBRE AISLADO}

R. Ramos Fernández ha estudiado recientemente dos ejemplos de aparente iconografía anómala: el vaso del joven y el 'dragón' y el vaso del varón a pie con su caballo (RAMOS FERNANDEZ, 1987 b). Intentémoslo verlos bajo esta nueva luz integradora.

El vaso del joven y el 'dragón', expuesto en el Museo de la Alcudia, es un ánfora de asas triples (RAMOS FERNANDEZ, 1987 b, f. 1; PERICOT, 1979, f. 126). En el anverso se representa la lucha del héroe y el monstruo. La escena tiene lugar en el marco de un inmenso paisaje floral. En el reverso, una gran ave hacia la izquierda, del tipo 'águi$1 a^{6}$, incompleta, vuelve su rostro para picar en una flor. Bajo el arranque de las asas sendas rosetas: una flor de cuatro sépalos y una roseta frontal.

La iconografía del anverso parece pues integrarse plenamente en la estructura iconográfica que hasta aquí hemos visto: es una realización concreta de aquélla. Como rasgo peculiar ofrece el vaso la imagen del hombre que se enfrenta al monstruo: el héroe es un adolescente imberbe y con largos cabellos de rizos individualizados. Viste una túnica corta y blande una lanza. Entra en contacto con el mons-

(6) Cf. el catálogo póstumo, con el dibujo de los vasos, de R. RAMOS FOLQUÉS, Alicante, en prensa.

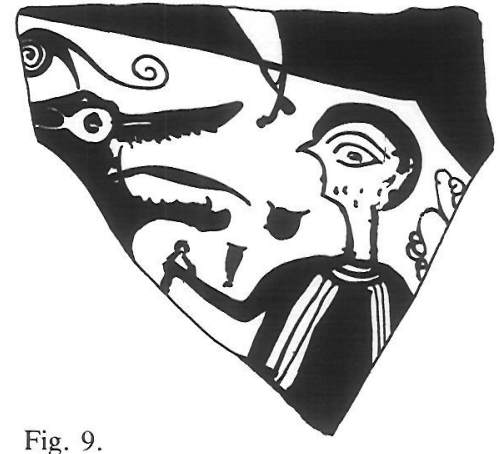

Fig. 9.

truo agarrándole de la inmensa lengua. Su característica no es tanto la fuerza excepcional - nada nos lo indica en la imagen- como su atrevimiento, su valor. Encajaría bien en el esquema del 'trickster' del folklore. El monstruo responde, por el contrario, al arquetipo del devorador: su cuerpo y, sobre todo, sus fauces son inmensas. Sobre el vientre se dibujan, geometrizadas, las costillas que nos indican el interior de sus entrañas, su capacidad de tragar. Resulta significativa la individualización del héroe frente al dragón y la enorme desproporción entre la escala humana y la sobrenatural. El tema responde a un motivo muy amplio, universal, de un rito de iniciación de adolescencia. El enfrentamiento por tanto debe ser en soledad entre ambos oponentes. Los monstruos individuales existen precisamente, con palabras de Peter von Blackenhagen, 'in order to offer potential heroes the occasion to prove their heroic mettle'. (VON BLACKENHAGEN, 1987, 85).

No es un ejemplo aislado este gran vaso de la Alcudia. Un fragmento de la Universidad de Burdeos, procedente de las excavaciones de Albertini en 1905, nos indica la misma secuencia: el joven frente al monstruo (GARCIA Y BELLIDO, 1943,

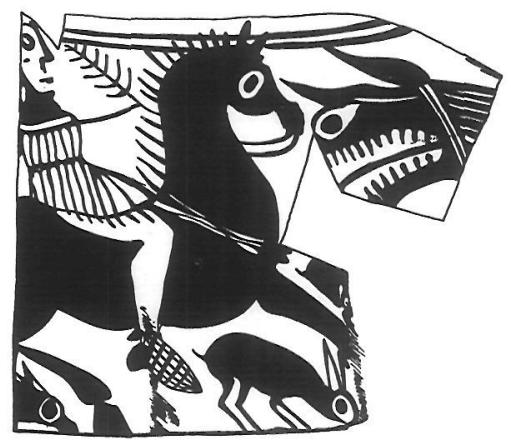

Fig. 10 . 
f. 21, según ALBERTINI, 1906-7). En este fragmento apunta ya la barba - cinco pequeños trazos sueltos- en el rostro del muchacho.

El tema puede revestirse de otras variantes, como en un fragmento procedente del Tossal de Manises, en Alicante: el mostruo se enfrenta a un jinete a caballo, que sostiene una palma en su diestra (LAFUENTE VIDAL, 1956, fig. 13, n. ${ }^{\circ}$ 10, IDEM, 1944, f. 31). Hombre y caballo, a la par, se retraen asustados. Bajo el caballo apunta de nuevo la alusión a la naturaleza: dos conejos husmean en el suelo con sus hocicos. El motivo del jinete a caballo asociado a los conejos, lo conocemos por el cipo funerario, en piedra, de Jumilla, en Murcia: una de las patas del caballo oprime al animal (MUÑOZ, 1983, 741-8; OLMOS-DE GRIÑO, 1985, 30-31, figs. 1011). Todas estas variantes parecen responder, de un modo u otro, a una representación de la muerte. El lobo devorador actúa, en el mundo ibérico, como monstruo que media entre el reino del aquende y del allende. Hallaremos la misma idea escatalógica en una patera de plata del siglo I a. de C., de Santisteban del Puerto, en Jaén, en la que la gran cabeza de lobo devuelve al hombre a través de sus entrañas al mundo del más allá (B. de GRIÑO-OLMOS, 1982). La imagen es ambigua, como en todo mito de tránsito: el mostruo devora o devuelve lo devorado, depende del punto de vista desde el que veamos la acción. Y así, las grandes fauces del lobo se abren para devorar, o para devolver, al guerrero caído - del que sólo vemos las piernas con las elegantes botas- en un fragmento de la Alcudia. De nuevo tenemos en todos estos ejemplos un esquema universal, bien conocido en el Mediterráneo (BOARDMAN, 1987, 73-84). Pero no es un mero motivo aislado, introducido de modo puntual o caprichoso, sino que se integra perfectamente en el paradigma iconográfico del mundo ibérico. Introduce el factor narrativo en esta iconografía prioritariamente simbólica.

También Rafael Ramos ha estudiado recientemente un segundo motivo de una gran ánfora de tres asas verticales de la Alcudia de Elche, con la imagen del varón que a pie conduce de las riendas a su caballo (RAMOS FERNANDEZ, 1987 b, f.2). La forma no es excepcional: hay otros ejemplos en la Alcudia de Elche que nos permiten ver la distribución complementaria en la iconografía de los tres paneles. En un ejemplo, muy próximo formalmente al nuestro, cubre cada uno de los tres paneles, respectivamente: un carnicero entre grandes flores que

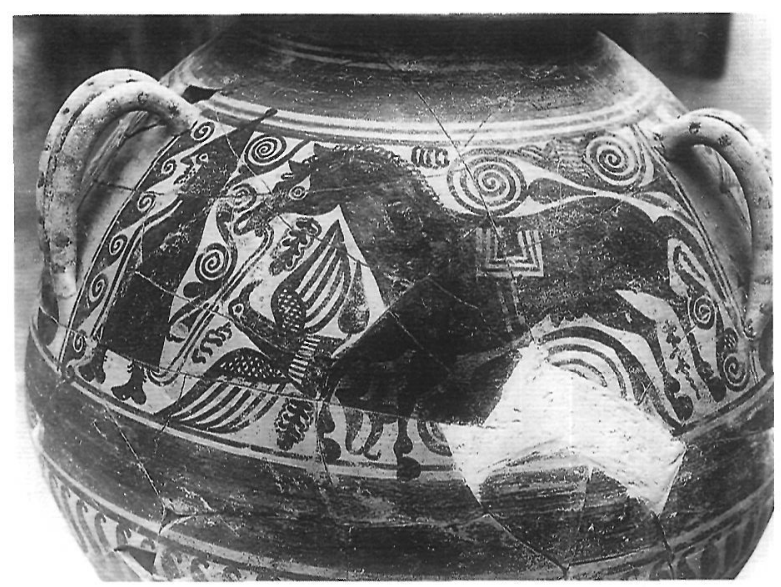

Fig. 11.

vuelve su rostro hacia la derecha; un águila, en similar posición; y, por último, una gran flor que brota del centro para desparramarse simétricamente a ambos lados.

En el ánfora del hombre con su caballo los otros dos paneles nos introducen en el paradigma conocido: el águila que pica en una flor; $y$, un panel con grandes flores y con dos metopas de rosetas de cuatro pétalos. En el motivo del varón y el caballo se ha aducido el influjo de paralelos mediterráneos, concretamente de estelas funerarias helenísticas en las que el varón se heroiza en el camino fúnebre. Es muy posible el influjo de estos paralelos, entre los que se ha aducido un relieve de Jávea (RAMOS FERNANDEZ, 1978 b, 235, n.8; FIGUERAS, 1945, 10, fig. 18). El motivo, ideológicamente exaltador, nos aproximaría en cierta medida estas escenas al de las estelas romanas dedicada a los equites singulares. No sabemos si, en nuestro caso, el varón que guía el caballo es el dueño mismo del caballo o su amigo, su compañero, su criado. Va envuelto en su manto y caperuza festiva, viste elegantes botas, con las puntas de los cordones cuidadosamente dibujadas. Un ave, hacia la izquierda, acompaña aquí con su vuelo el sentido de la marcha. Lo importante de nuevo es documentar un posible préstamo formal e integrarlo en la ideología ibérica. Hemos aludido en el apartado escultórico al caballo como imagen funeraria. Caballos sin montar, a veces igualmente preparados con la silla como en nuestro caso, son la decoración de monumentos funerarios ibéricos en la provincia de Albacete, en el hinterland de penetración de este área del Sureste (CHAPA, 1986, 103, N 153: Casas de Juan Nú- 
ñez: BLAZQUEZ y GONZALEZ NAVARRETE, 1985, f. 24). Aluden simultáneamente al tránsito y al status social de allí enterrado. Pero además esta representación del ánfora no es ajena al universo iconográfico de la misma cerámica ilicitana: se integra en las imágenes, florales y animales, tantas veces aludidas. Ya vimos también inserto al caballo en ese mundo divino. El modelo foráneo, mediterránmeo, ha servido seguramente también aquí para introducir otra nueva realización antropomórfica en el universo simbólico del ibero. La novedad se incorpora al viejo esquema, transformándolo y transformándose en su integración.

De este modo podríamos incluir otras lecturas: la efigie del jinete en su caballo, a veces en el contexto heroico de la caza, otras armado con lanza, pero siempre aislado, en su representación heroificadora. Esta imagen individualizada se representa en los dos lados de una gran tinaja de la Alcudia (PERICOT, 1979, figs., 148-9). Le acompaña el habitual cortejo de animales, tantas veces citado: conejos, aves y peces, que pertenecen al reino de la gran diosa. Tampoco suelen en estas escenas faltar las rosetas -incluso con las volutas aladas- bajo el vientre de los caballos, lo que asocia al héroe al mundo sobrenatural y divino: claramente no son escenas de la vida cotidiana (PERICOT, 1979, figs. $148-9,166)$. En alguno de estos casos podríamos incluso pensar en un accensus: la marcha a caballo que relaciona al guerrero con el mundo superior.

Hasta aquí los ejemplos. Pensamos que este camino puede ser fecundo si ampliamos la encuesta iconográfica a los restantes talleres del Levante y del Sureste ibéricos. Esta encuesta deberá someterse en otro lugar a la estructuración de una lectura semiótica. Hemos formulado en un reciente trabajo las perspectivas que ofrece este planteamiento nuevo (OLMOS, 1990). Preferimos este camino integrador a aquellos otros de las búsquedas inacabables y eruditas de paralelos y citas, en un comparatismo unificador que todo lo iguala aplicando al pasado unas categorías estériles de nuestra modernidad. Los iberos - como los griegos o los etruscos- fueron, ante todo, ellos mismos. Una tautología en apariencia ingenua pero que, a veces, por lo simple, resulta aún preciso recordar.

Madrid, Febrero de 1989.

\section{BIBLIOGRAFÍA}

ABAD, L. 1983, 'Un conjunto de materiales de la Serreta de Alcoy', Lucentum, II, 173-197.

AELLEN, CHR., CAMBITOLOGLOU, A. y CHAMAY, J. 1986, Le Peintre de Darius et son milieu, Ginebra.

ALBERTINI, E. 1906-7, 'Fouilles d'Elche', Bulletin Hispanique VIII-IX.

ALMAGRO GORBEA, M.J. 1980, Corpus de las terracotas de Ibiza, Madrid.

ARCE, J., 1990: 'Estrabón sobre la Bética', Coloquio sobre la tabula Irmitana y la Bética, Sevilla, 213-222.

ARIES PH., L'homme devant la mort, París, 1977.

ARRIBAS, A., 1965. Los iberos, Barcelona.

BALLESTER TORMO, I. 1943, 'Sobre una posible clasificación de las cerámicas de San Miguel con escenas humanas', AEspA, 16, 64-77.

BALLESTER TORMO, 1. et Alii 1954, Cerámica del cerro de San Miguel de Líria, Corpus Vasorum Hispanorum, Madrid.

BENOIT, F. 1953, 'Chevaux du Levant Ibérique, Celtisme ou Méditerraneisme?', $A P L$, IV, 211-218.

BEAZLEY, J.D. 1947 (1976), Etruscan Vase Painting, Oxford, 1947, (Reimpr. New York, 1976).

BERARD, CL. 1974, 'Anodoi', Recherches sur l'imagerie des passages chthoniems. Bibliotheca Helvetica Romana, 13.

BIANCHI BANDINELLI, R. 1961, Archeologia e cultura.

BLANCO, A., 1960, 'Die klassischen Wurzeln der Iberischen Kunst', $M M, \mathrm{I}, 101$ ss.

BLANCO, A., 1963, 'Tarros de cerámica ibérica andaluza', Oretania, 14-15. Mayo-Diciembre, 87-99.

BLACKENHAGEN, Peter H. VON 1987, 'Easy Monsters' en FARKAS, A., HARPER, P.O. y HARRISON, E.B. (eds.), Monsters and Demons in the Ancient and Medieval Worlds, Papers presented in honour of Edith Porada, 85-94.

BLAZQUEZ, J.M. 1956, 'Las diosas sagradas de Elche (Alicante) ${ }^{\prime}$. Congresos internacionales de Ciencias Prehistóricas y protohistóricas, Actas de la IV sesión, Madrid, 1954. Zaragoza.

BLAZQUEZ, J.M. 1957. 'Aportaciones al estudio de las religiones primitivas de España', $A E s p A, 30,15$ ss.

BLAZQUEZ, J.M., 1975 Diccionario de las religiones prerromanas de Hispania, Madrid.

BLAZQUEZ, J.M., 1975 B. Tartessos, Salamanca.

BLAZQUEZ, J.M. 1977, Imagen y Mito, Madrid.

BLAZQUEZ, J.M. y GONZALEZ NAVARRETE, J., 1985, 'The Phokaian Sculture of Obulco in Southern Spain', $A J A$, 89, 61-69, pls. 9-20.

BOARDMAN, J. 1987 'Very Like a Whale', en FARKAS, A., HARPER, P.O. y HARRISON, E.D. (eds.) Classical Sea Monsters, en Monsters and Demons in the Ancient and Medieval Worlds, Papers presented in honour of Edith Porada, 73-84.

Este trabajo se ha realizado dentro del Proyecto de Investigación «Imagen, mito y sociedad en la cultura ibérica», aprobado por la DGICYT (n. ${ }^{\circ}$ PB89-0006-(02-01). Una versión inglesa ha sido publicada en la revista Mediterranean $A r-$ chaeology, núm. II y III, Sydney 1989 y 90. En la versión castellana se han incluido algunas pequeñas modificaciones $y$ añadidos. 
BONET, H., y MATA, C. 1986, 'Imitaciones de Cerámica Campaniense en la Edetania y Contestania', $A E s p A, 61$, pp. 5-38.

BOSCH GIMPERA, P. 1915, El problema de la cerámica ibéri$c a$, Madrid.

BOSCH GIMPERA, P. 1928, 'Relaciones entre el Arte Griego y el Ibérico', $A P L$, I, 163-178.

BOSCH GIMPERA, P. 1958, Todavia el problema de la cerámica ibérica, México.

CABRÉ, J. 1945, Corpus Vasorum Hispanorum: Cerámica de Azaila, Madrid.

CABRERA, P. y GRIÑO, B. de, 1986, 'La dama de Baza: ¿una diosa tejedora en el allende?', Coloquio sobre el Puteal de la Moncloa, Madrid, 193-206.

CABRERA, P. y OLMOS, R., 1985, 'Die Griechen in Huelva', $M M, 26,61-74$.

CARPENTER, Rhys 1925, The Greeks in Spain, Bryn Mawr, Pennsylvania.

CASTILlO, A. del 1943, 'La cerámica Ibérica de Ampurias: cerámica del Sureste', AEspA, 16, 1-48.

CHAPA, T. 1985, La escultura ibérica zoomorfa. Madrid.

CHAPA, T. 1986, 'Influjos Griegos en la escultura zoomorfa ibérica“, Iberia Graeca II. Madrid.

DOMINGUEZ MONEDERO, A. 1984, 'La escultura animalística contestana como exponente del proceso de helenización del territorio', Arqueología espacial. Coloquio sobre la distribución y relaciones entre los asentamientos, Teruel, $\mathrm{n} .^{\circ}$ 4, 141-160.

ELVIRA, M.A. 1979, Aproximación al 'estilo florido o rico' de la cerámica de Liria', AEspA. 52, 1979, 205-225.

FERNANDEZ DE AVILES, A. 1944, 'Rostros humanos, de frente, en la cerámica ibérica', Ampurias, VI, 161-178.

FIGUERAS, F., 1945, 'Panorama arqueológico de Jávea y sus cercanias' $A E \operatorname{ssp} A, 18,1945,1-33$.

FIGUERAS, F. 1956, 'La Necrópolis ibero-púnica de la Albufereta de Alicante'. Estudios Ibéricos, IV, Valencia.

FLETCHER, D., 1943, 'Sobre la cronología de la cerámica ibérica', $A E \operatorname{sp} A, 16,109-115$.

FRONTISI-DUCROUX, F., 1987, 'La morte en face‘, MHTIS, 197-213.

FROTINGHAM, A.L. 1911, 'Medusa, Apollo and the Great Mother', $A J A, 15,349-377$.

GARCIA Y BELLIDO, A. 1943, 'Algunos problemas de arte y cronología ibéricos', AEspA, 16, 78-108.

GARCIA Y BELLIDO, A. 1943 b, La Dama de Elche y el conjunto de piezas reingresadas a España en 1941. Madrid.

GARCIA Y BELLIDO, A. 1947, Ars Hispaniae, I, Madrid.

GARCIA Y BELLIDO, A. 1954, (1976) en RAMON MENÉNDEZ PIDAL, Historia de España, I, 3, Madrid, (ed. de 1976), 626-636.

GARCIA Y BELLIDO, A. 1980, Arte Ibérico en España, Madrid.

GILOTTA, F., 1985, Gutti e askoi a rilievo italioti ed etruschi, Roma.

GONZALEZ PRAT, A. 1986, 'La Peña Negra V', Noticiario Arqueológico Hispánico, 27.

GRIÑO, B. de 1987, 'Aproximación al problema de las divinidades femeninas en la Península Ibérica en época prerromana', Grecs et ibéres, $R E A, 89,339-347$.

GRIÑO, B. de y OLMOS, R. 1982, 'La patera de Santisteban del Puerto (Jaén)', Estudios de Iconografía $I$.

HOZ, J. de 1983, AION, Annali del Seminario di studi del Mondo Classico, V, 27-62.
JOHNSON, F.P. 1949, 'Eight Pieces of pottery', $\boldsymbol{A J A}, 43$, 244-255.

KOSSATZ, A. 1985, 'Apulischer Kernos', $A A$, 229-239.

KOSSATZ, A. 1986, 'Osservazioni sulle nascite di Afrodite ed Atena nell'arte greca', Coloquio sobre el Puteal de la Moncloa, Madrid, 1986.

KUKAHN, E. 1957, 'Busto femenino de terracotta de origen rodio en el ajuar de una tumba de Ibiza“, $A E \operatorname{sp} A, 30,3-14$.

KUKAHN, E. 1962, 'Los símbolos de la gran diosa en la pintura de los vasos ibéricos levantinos', Caesaraugusta, XIX-XX.

LAFUENTE VIDAL, J. 1944, 'Algunos datos concretos de la provincia de Alicante sobre el problema cronológico de la cerámica ibérica', AEspA, XIV, 68-87.

LAFUENTE VIDAL, J. 1952, 'Influencia de los cultos cartagineses en los motivos artísticos del Sureste español', $A P L, 3$.

LAMB, W. 1932, 'Grey wares from Lesbos', JHS, LII, 1-12.

LANGLOTZ, E. 1966, Die kulturelle und künstlerische Hellenisierung der Küsten des Mittelmeeres durch die Stadt Phokäia. Köln y Opladen.

LEVI, P. 1935, Il Museo Civico de Chiusi.

LILLO CARPIO, P. 1983, 'Una aportación al estudio de la religión ibérica: la diosa de los lobos de la Umbría de Salchite, Moratalla (Murcia)', XVI CNA, (Murcia y Cartagena, 1982), Zaragoza, 769-787.

LOHMANN, H.1979, Grabmäler auf Unteritalischen Vasen, Berlín.

LLOBREGAT, E. 1970, 'Revisión del papel de los cartagineses en la Historia Antigua del país Valenciano', I Congreso de historia del pais Valenciano, Valencia.

LLOBREGAT, E. 1972, Contestania Ibérica, Alicante.

LLOBREGAT, E. 1981, Papeles del Laboratorio de arqueología de Valencia, 16, 149-164.

LLOBREGAT, E. 1989, 'La Dama del Cabezo Lucero', Historia $16, \mathrm{n}^{\circ} 154,95-105$.

MARCADE, J. 1985, en METZGER (ed). EI $\triangle$ O $\Lambda$ OחOIIA, $A c$ tes du Colloque sur les problèmes de l'image dans le monde classique, 27-39.

MARIN CEBALLOS, M.C. 1987, ‘¿Tanit en España?’, Lucentum, VI, 43-79.

MAZZEI, M., 1987, 'Nota su un grupo di vasi policromi decorati con scene di combattimento da Arpi (FG) ${ }^{\varsigma}$, AION ArchStAnt, 167-188.

MOREL, J.P. 1981, Céramique campanienne: les formes. BEFAR, 242, Roma.

MUÑOZ, A.M a , 1983, 'Cipo funerario ibérico decorado con esculturas', XVI Congreso Nacional de Arqueología, Murcia, 1982, Zaragoza, 741-8.

NORDSTRÖM, S. 1968, 'Los ojos en los oenochoes ibéricos en el Levante español, Stockholm', Studies in Classical Archaeology, V,: Opuscula $K$. Kerenyi dedicata.

NORDSTRÖM, . 1968, 'Representaciones de aves en la cerámica ibérica del sureste de España', Op. Rom. VI, Lund, 97-120.

NORDSTRÖM, S. 1969, 1973, La céramique peinte ibérique de la Province d'Alicante, Studies in Classical Archaeology, VIII, Stockholm, vol. I, 1969; vol. II, 1973.

OBERMAIER, H. y HEISS, C.W. 1929 'Iberische Prunkkeramik', IPEK.

OLMOS, R. 1981, Vaso griego y caja cineraria en la Bastetania ibérica, Homenaje a Concepción Fernández Chicarro, Madrid, 259-268. 
OLMOS, R. 1982, 'La cerámica griega en el Sur de la Península ibérica: la aportación de Huelva', PP, 204-7, 393-406.

OLMOS, R. 1984, 'Interprétations ibériques des vases grecques: le IVe.s.av.J.C.', Ancient Greek and Related Pottery, Allard Pierson Series, V, 218-223.

OLMOS, R. 1986, 'Quelques observations sur l'assimilation de l'iconographic grecque par le monde ibérique', $B C H$, Suppl. $X I V, 155-166$

OLMOS, R. 1987, 'Posibles vasos de encargo en la cerámica ibérica del Sureste', $A E s p A, 60,28-42$.

OLMOS, R. y GRIÑO, B. de, 1985, 'El entorno póntico y la Península ibérica‘, Archeologia, XXXVI, Varsovia, 15-53.

OLMOS, R. 1989, 'El Corpus Vasorum Antiquorum, setenta años después‘, $A E \operatorname{spA}, 62,292-303$.

OLMOS (en prensa), 'Imitaciones, producción y sociedad: algunas consideraciones en torno a la cerámica ibérica', $\mathrm{Ho}$ menaje a Emeterio Cuadrado, Murcia.

OLMOS, R. 1990, 'Nuevos enfoques y propuestas de lectura en el estudio de la iconografía ibérica', en A. VILA (ed.), Nuevas tendencias en arqueología, CSIC. Madrid, en prensa.

PAGE, V. 1984, Imitaciones de influjo griego en la cerámica ibérica de Valencia, Alicante y Murcia, Iberia Graeca, 2, Madrid.

PARIS, P. 1904-5, Essai sur l'art et l'industrie de l'Espagne primitive, París, I, 1905, II 1904.

PEREIRA, J., 1979, 'La cerámica ibérica procedente de Toya (Peal de Becerro, Jaén) en el Museo Arqueológico Nacional', $T P, 36,289-348$.

PERICOT, L. 1979, Cerámica ibérica, Barcelona.

PRESEDO, F. 1973, La Dama de Baza, Madrid.

PRESEDO, F. 1982, 'La Necrópolis de Baza', Excavaciones Arqueológicas en España.

P.S., J. 1911-12, 'El Vas ibèric d'Archena', Annuari d'Estudis Catalans, 1911-12, 685.

RAMOS FERNANDEZ, R. 1982, 'Precisiones para la clasificación de la cerámica ibérica', Lucentum, I, 17-133.

RAMOS FERNANDEZ, R. 1987, El Museo Arqueológico de Elche, Elche.

RAMOS FERNANDEZ, R. 1987, 'Demarcación ibérica en el parque de Elche', XVIII Congreso Nacional de Arqueología, Zaragoza, 681-694.

RAMOS FERNANDEZ, R. 1987 b, 'Iconografía funeraria en algunas cerámicas ibéricas de la Alcudia', $A E s p A, 60$, 231-236.

RAMOS FERNANDEZ, R. 1989, 'Nuevos hallazgos en la Alcudia de Elche', AEspA, 62.

RAMOS FOLQUÉS, A. 1943, 'Hallazgos cerámicos de Elche y algunas consideraciones sobre el origen de ciertos temas', AEsp, 52, 328-335.

RAMOS FOLQUÉS, A. 1944, 'La Dama de Elche', AEspA, 56.
RAMOS FOLQUES, A. 1945, La Dama de Elche. Nuevas aportaciones a su estudio, Madrid.

RAMOS FOLQUÉS, A. 1947, 'La Dama de Elche. Datos para su cronología. El problema del nivel arqueológico de su hallazgo', III Congreso Arq. S.E., Murcia.

RAMOS FOLQUÉS, A. 1950, 'La influencia del arte griego, etrusco y púnico sobre el ibérico", VII Congreso Arq. S.E., Alcoy.

RAMOS FOLQUÉS, A. 1950 b, 'Hallazgos escultóricos en la Alcudia de Elche', AEspA, 23, 353-359.

RAMOS FOLQUÉS, A. 1951, VI Congreso Arqueológico del Sudeste, 195-200.

RAMOS FOLQUÉS, A. 1955, 'Sobre escultura y cerámica ilicitanas', Estudios ibéricos, 3, Valencia.

RAMOS FOLQUÉS, A. 1959, 'Los jinetes con lanza en la cerámica pintada de la Alcudia', VI Cong. Arq. Nac., Oviedo.

RAMOS FOLQUÉS, A. 1966, 'Un kernos y otros vasos de la Alcudia de Elche', IX Congreso Nacional de Arqueología, (Valladolid, 1965), Zaragoza, 296-300.

RAMOS FOLQUÉS, A. 1966, 'Estratigrafía de la Alcudia de Elche', Saitabi, XVI.

RAMOS FOLQUÉS, A. 1966 b, 'Un kernos y otros vasos de la Alcudia de Elche', IX Congreso Nacional de Arqueología, Valladolid.

RAMOS FOLQUÉS, A. 1970, Excavaciones en la Alcudia (Elche), SIP, Trabajos varios, $n^{\circ} 39$, Valencia.

RAMOS FOLQUÉS, A. 1973, 'El nivel ibero-púnico de la Alcudia de Elche, Alicante', Cuadernos de Estudios Ligures, 363-383.

RAMOS FOLQUÉS, A. y RAMOS FERNANDEZ, R. 1976, 'Excavaciones en la Alcudia de Elche (1969-1973)', Excavaciones Arqueológicas en España, 91.

ROSS HOLLOWAY, R. 1987, 'Sostratos kalós', Studi per Laura Breglia III, Suppl. $n^{\circ} 4$ Bull. di numismatica.

SANCHEZ, M.J. y BLASCO, E. y GUARDIOLA, A., 1986, Portus Ilicitanus. Datos para una sintesis. Alicante.

SANDARS, H. 1913, The Weapons of the Iberians, Oxford.

SANMARTI, E. 1978, La cerámica campaniense de Emporion y Rhode, Barcelona, I; II.

STENGEL, P. 1910, Opferbräuche der Griechen, (reimp. 1972).

STOOP, M.W. 1960, Floral Figurines in South Italy.

SZYLAGYI, J.G.Y. 1975, 'A propos des vases à Figures Rouges en couleurs superposées de l'Italie méridionale', BMusHong, 44, 1975, 13-28.

TRENDALL, A.D. y MAC PHEE, J. 1987, Greek Red-Figured Fish Plates, Antkunst, Beiheft 14, Basilea.

TRIAS, G., 1967, Cerámicas griegas en la Península Ibérica, Valencia.

VERNANT, J.P., 1981, Mélanges Poliakov, 141-145.

VERNANT, J.P., et alii, 1984, La Cité des Images, Parìs. 